NATIONAL LABORATORY

MANAGED BY UT-BATTELLE

FOR THE DEPARTMENT OF ENERGY

\title{
TRADE STUDY ON AGGREGATION OF MULTIPLE 10-KW SOLID OXIDE FUEL CELL POWER MODULES
}

\author{
B. Ozpineci \\ L. M. Tolbert \\ D. J. Adams
}

Oak Ridge National Laboratory

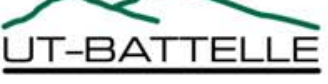




\section{DOCUMENT AVAILABILITY}

Reports produced after January 1, 1996, are generally available free via the U.S. Department of Energy (DOE) Information Bridge.

Web site http://www.osti.gov/bridge

Not available externally.

Reports are available to DOE employees, DOE contractors, Energy Technology Data Exchange (ETDE) representatives, and International Nuclear Information System (INIS) representatives from the following source.

Office of Scientific and Technical Information

P.O. Box 62

Oak Ridge, TN 37831

Telephone 865-576-8401

Fax 865-576-5728

E-mail reports@adonis.osti.gov

Web site http://www.osti.gov/contact.html

This report was prepared as an account of work sponsored by an agency of the United States Government. Neither the United States Government nor any agency thereof, nor any of their employees, makes any warranty, express or implied, or assumes any legal liability or responsibility for the accuracy, completeness, or usefulness of any information, apparatus, product, or process disclosed, or represents that its use would not infringe privately owned rights. Reference herein to any specific commercial product, process, or service by trade name, trademark, manufacturer, or otherwise, does not necessarily constitute or imply its endorsement, recommendation, or favoring by the United States Government or any agency thereof. The views and opinions of authors expressed herein do not necessarily state or reflect those of the United States Government or any agency thereof. 


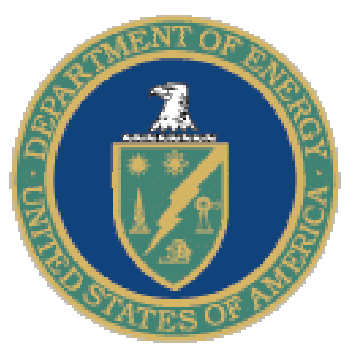

ORNL/TM-2004/248

Engineering Science and Technology Division

\title{
Trade Study on Aggregation of Multiple 10-kW Solid Oxide Fuel Cell Power Modules
}

\author{
B. Ozpineci \\ L. M. Tolbert \\ D. J. Adams
}

November 29, 2004

OAK RIDGE NATIONAL LABORATORY

Oak Ridge, Tennessee 37831

managed by

UT-BATTELLE, LLC

for the

U.S. DEPARTMENT OF ENERGY

under contract No. DE-AC05-00OR22725 


\section{TABLE OF CONTENTS}

LIST OF FIGURES iv LIST OF TABLES.... $\mathrm{v}$ ACRONYMS AND ABBREVIATIONS ………............................................................. vi ABSTRACT. EXECUTIVE SUMMARY vii viii

1. INTRODUCTION

2. FUEL CELL POWER ELECTRONICS INTERFACE ………………………………...... 3

2.1 FUEL CELL V-I POLARIZATION CURVE ………............................................ 3

2.2 FUEL CELL POWER ELECTRONICS INTERFACE ………………………......... 4

2.3 OTHER POWER CONVERTER ISSUES ............................................................. 6

2.3.1 Regeneration ............................................................................. 6

2.3.2 Fuel Cell Dynamic Response............................................................... 6

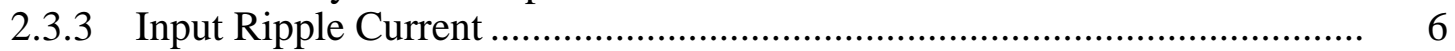

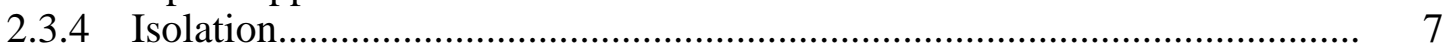

2.3.5 Stock Voltage Variation.................................................................... 7

3. POSSIBLE ARCHITECTURES ……………………............................................ 8

3.1 SERIES ARCHITECTURE............................................................................. 8

3.1.1 Case A - Series Architecture with Three-Phase Inverter ............................. 9

3.1.2 Case B - Series Architecture with Three-Phase Inverter and DC-DC Voltage Regulator........................................................................ 11

3.1.3 Comparison .................................................................................. 11

3.1.4 Advantages and Disadvantages........................................................... 12

3.2 CASE C - DC BUS DISTRIBUTION ARCHITECTURE .................................... 12

3.3 CASE D - HFAC DISTRIBUTION ARCHITECTURE …….............................. 14

3.4 CASE E - CASCADED MULTILEVEL ARCHITECTURE................................. 16

3.5 CASE F - MULTILEVEL ARCHITECTURE …………………......................... 19

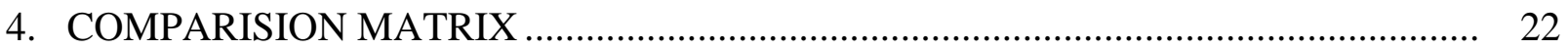

4.1. COST (CAPITAL AND OPERATING) ……………......................................... 23

4.2. CONTROL COMPLEXITY ……………………........................................... 23

4.3 RELIABILITY .................................................................................... 24

4.4 AVAILABILITY (AT POWER SYSTEM AND DEVICE LEVELS) .................... 24

4.5 FAULT TOLERANCE ................................................................................... 24

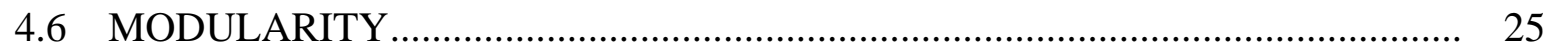

4.7 ENERGY CONVERSION EFFICIENCY …….................................................. 25

4.8 EASE OF MASS CUSTOMIZATION TO ENABLE MASS PRODUCTION TO DRIVE DOWN COSTS ............................................................................. 26

5. LEVEL REDUCTION TECHNIQUE FOR MULTILEVEL CONVERTERS................ 28

5.1 LEVEL REDUCTION TECHNIQUE USING A CASCADED MULTILEVEL DC-DC CONVERTER 


\section{TABLE OF CONTENTS (cont'd)}

5.1.1 Case G - Multilevel DC-DC Converter................................................ 30

5.1.2 Evaluation ........................................................................................... 31

5.1.2.1 Power supplied ........................................................................ 31

5.1.2.2 Fuel cell utilization ..................................................................... 32

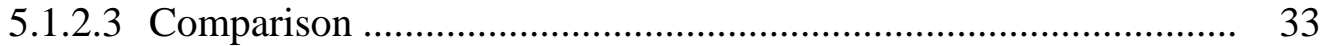

5.1.3 Parallel Operation .................................................................................. 34

5.1.4 Parallel-Series (Matrix) Operation............................................................ 35

5.2 LEVEL REDUCTION TECHNIQUE USING CASCADED MULTILEVEL INVERTERS....................................................................................... 36

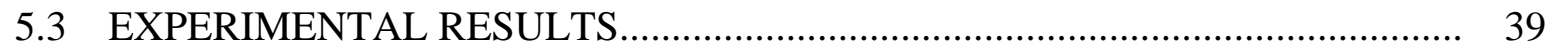

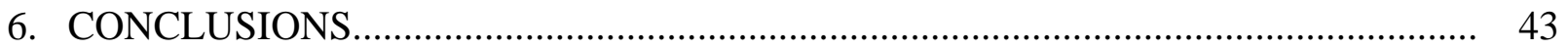

6.1 NOTES AND RECOMMENDATIONS ............................................................ 43

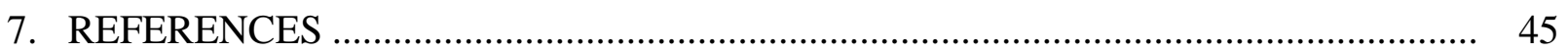




\section{LIST OF FIGURES}

Page

2.1 Theoretical V-I polarization curve of the fuel cell used in calculations........................ 3

2.2 Polarization curve for a $10 \mathrm{~kW}$ solid oxide fuel cell module .......................................... 4

2.3 Typical fuel cell power electronics interface block diagram......................................... 5

2.4 Typical DC-DC boost converter......................................................................... 5

2.5 Isolated DC-DC boost converter ...................................................................... 5

3.1 Block diagram of the series architecture …………….............................................. 8

3.2 Parallel architecture .......................................................................................... 9

3.3 Case A - Series architecture with a three-phase inverter .............................................. 9

3.4 Block diagram for Case B .................................................................................... 9

3.5 Case B - Series architecture with a DC-DC voltage regulator and a three-phase 11

3.6 Block diagram of the DC bus distribution architecture................................................ 13

$3.7 \quad$ Typical H-bridge inverter ....................................................................................... 14

3.8 Block diagram of the HFAC distribution architecture ............................................... 15

3.9 Typical single-phase to three-phase matrix converter ................................................... 15

3.10 Block diagram of the cascaded multilevel architecture............................................... 17

3.11 One phase of a cascaded seven-level inverter ........................................................ 18

3.12 Waveforms of a cascaded seven-level inverter ............................................................ 18

3.13 Block diagram of the multilevel architecture .............................................................. 19

3.14 One phase of a diode clamped seven-level inverter .................................................. 20

5.1 Static characteristics for up to 10 fuel cells in series and level reduction technique ... 29

5.2 Multilevel DC-DC converter output voltage for each case ........................................... 29

5.3 Multilevel DC-DC converter connected to a three-phase inverter ................................ 30

5.4 Power supplied for each case ............................................................................... 31

$5.5 \quad$ Fuel cell utilization for each case ............................................................................ 32

5.6 Modified fuel cell utilization for each case .............................................................. 33

$5.7 \quad$ Proposed parallel operation of fuel cells ………............................................... 34

5.8 Static characteristics for up to five fuel cells in parallel .............................................. 35

5.9 Static characteristics for up to five fuel cells in parallel and up to ten in series........... 36

5.10 Fundamental switching sine triangle wave comparison ............................................... 37

5.11 Modulation index correction plot ............................................................................ 38

5.12 Output voltage waveform simulated for high-load to low-load transition .................... 38

5.13 THD with respect to the modulation index ………............................................... 39

5.14 Seven-level output voltage waveform for low fuel cell load ....................................... 40

5.15 FFT of the voltage waveform in Fig. 5.14 ............................................................... 40

5.16 Eleven-level output voltage waveform for high fuel cell load ................................... 41

5.17 FFT of the voltage waveform in Fig. 5.16 ................................................................... 41 


\section{LIST OF TABLES}

Page

4.1 The architecture comparison matrix

22 


\section{ACRONYMS AND ABBREVIATIONS}

$\begin{array}{ll}\text { AC } & \text { Alternating Current } \\ \text { CO } & \text { Carbon Monoxide } \\ \mathrm{CO}_{2} & \text { Carbon Dioxide } \\ \text { DC } & \text { Direct Current } \\ \text { DOE } & \text { Department of Energy } \\ \text { FE } & \text { Fossil Energy } \\ \mathrm{H}_{2} \mathrm{O} & \text { Water } \\ \mathrm{HFAC} & \text { high frequency AC } \\ \text { kW } & \text { Kilowatt } \\ \text { LHV } & \text { Lower Heating Value } \\ \text { PWM } & \text { Pulse Width Modulation } \\ \text { SECA } & \text { Solid State Energy Conversion Alliance } \\ \text { SOFC } & \text { Solid-oxide fuel cell } \\ \text { U.S. } & \text { United States } \\ \text { V } & \text { Volts direct current }\end{array}$




\begin{abstract}
According to the Solid State Energy Conversion Alliance (SECA) program guidelines, solid oxide fuel cells (SOFC) will be produced in the form of 3-10 kW modules for residential use. In addition to residential use, these modules can also be used in apartment buildings, hospitals, etc., where a higher power rating would be required. For example, a hospital might require a $250 \mathrm{~kW}$ power generating capacity. To provide this power using the SECA SOFC modules, 25 of the $10 \mathrm{~kW}$ modules would be required. These modules can be aggregated in different architectures to yield the necessary power. This report will show different approaches for aggregating numerous SOFC modules and will evaluate and compare each one with respect to cost, control complexity, ease of modularity, and fault tolerance.
\end{abstract}




\section{EXECUTIVE SUMMARY}

Solid oxide fuel cell technology being advanced under the Solid State Energy Conversion Alliance (SECA) Program is a highly promising power generation technology for use with both fossil fuels and hydrogen. The electrical efficiency of a fuel cell can be greater than $70 \%$ in theory (the current SOFC technology has demonstrated 47\% net AC power efficiency at fuel lower heating value (LHV)). The cogeneration of electrical energy and heat improves the exploitation of primary energy achieving better than 80\% LHV energy efficiency.

The goal of the SECA Program is to develop commercially-viable ( $\$ 400 / \mathrm{kW}) 3$ to $10 \mathrm{~kW}$ SOFC power generation systems by year 2010. SOFC systems offer fuel flexibility as they are compatible with conventional fuels such as hydrogen, coal, natural gas, gasoline, or diesel and are attractive alternatives to current technologies in diverse stationary, mobile, and military applications. SOFC systems are very efficient, from 40 to 60 percent in small systems and up to 85 percent in larger co-generation applications. The electrochemical conversion in an SOFC takes place at a lower temperature $\left(650\right.$ to $\left.850^{\circ} \mathrm{C}\right)$ than combustion-based technologies, resulting in decreased emissions particularly nitrogen oxides, sulfur oxides, and particulate matter. $\mathrm{CO}_{2}$ emissions are greatly reduced due to the high efficiency of SOFCs. In addition, the SOFC power module is well suited to capture $\mathrm{CO}_{2}$ and enables efficient implementation of $\mathrm{CO}_{2}$ sequestration strategies.

Each fuel cell operates at approximately 0.7 volts; therefore, several fuel cells are grouped together into a fuel cell stack to produce higher voltages. The SECA program is targeting solid oxide fuel cell (SOFC) modules in the 3-10 kW range to be made available for residential applications. In addition to residential use, SOFC modules can also be aggregated for use in apartment buildings, hospitals, etc., where a higher power rating would be required. For example, a hospital might require a $250 \mathrm{~kW}$ power generation capacity. To provide this power using 10-kW SOFC modules, 25 modules must be aggregated electrically. These modules can be aggregated in different architectures to yield the necessary power. This report describes five different architectures for aggregating numerous SOFC modules and provides a trade-study comparison of each architecture with respect to cost, control complexity, ease of modularity, and fault tolerance. 


\section{INTRODUCTION}

Human dependence on electricity is growing faster with time. Coal, oil, and other energy sources have been used to generate electricity for more than a century. Today, as conventional fossil energy (FE) supplies, such as oil, coal and natural gas are rapidly depleting, new energy sources are required to replace them. Major pollution concerns are $\mathrm{NO}_{\mathrm{x}}$, carbon dioxide $\left(\mathrm{CO}_{2}\right)$, and $\mathrm{SO}_{2}$ pollution is a major concern. To overcome these problems, the United States (U.S.) Department of Energy (DOE) Office of Fossil Energy is pursuing research and development programs leading to more efficient and environmentally friendly power generation and enabling effective power generation in a future hydrogen economy [1, 2].

Solid-oxide fuel cell (SOFC) technology being advanced under the Solid State Energy Conversion Alliance (SECA) Program is a highly promising power generation technology for use with both fossil fuels and hydrogen. The electrical efficiency of a fuel cell can be greater than $70 \%$ in theory [the current SOFC technology has demonstrated $47 \%$ net alternating current (AC) power efficiency at fuel lower heating value (LHV)]. The cogeneration of electrical energy and heat improves the exploitation of primary energy, achieving better than 80\% LHV energy efficiency.

The goal of the SECA Program is to develop commercially-viable (\$400/kilowatt [kW[) 3 to $10 \mathrm{~kW}$ SOFC power generation systems by the year 2010. SOFC systems offer fuel flexibility, as they are compatible with conventional fuels such as hydrogen, coal, natural gas, gasoline, or diesel and are attractive alternatives to current technologies in diverse stationary, mobile, and military applications. SOFC systems are very efficient, from 40 to $60 \%$ in small systems and up to $85 \%$ in larger co-generation applications. The electrochemical conversion in an SOFC takes place at a lower temperature $\left(650\right.$ to $\left.850^{\circ} \mathrm{C}\right)$ than combustion-based technologies, resulting in decreased emissions - particularly nitrogen oxides, sulfur oxides, and particulate matter. $\mathrm{CO}_{2}$ emissions are greatly reduced because of the high efficiency of SOFCs. In addition, the SOFC power module is well suited to capture $\mathrm{CO}_{2}$ and enables efficient implementation of $\mathrm{CO}_{2}$ sequestration strategies.

Each fuel cell operates at approximately $0.7 \mathrm{~V}$; therefore, several fuel cells are grouped together into a fuel cell stack to produce higher voltages. The SECA program [3] is targeting SOFC modules in the 3-10 kW range to be made available for residential applications [4-6]. In

addition to residential use, SOFC modules can also be aggregated for use in settings such as 
apartment buildings and hospitals, where a higher power rating would be required. For example, a hospital might require a $250 \mathrm{~kW}$ power generation capacity. To provide this power using 10-kW SOFC modules, 25 modules must be aggregated electrically. These modules can be aggregated in different architectures to yield the necessary power. This report describes five different architectures for aggregating numerous SOFC modules and provides a trade-study comparison of each architecture with respect to cost, control complexity, ease of modularity, and fault tolerance. 


\section{FUEL CELL POWER ELECTRONICS INTERFACE}

\subsection{FUEL CELL V-I POLARIZATION CURVE}

The general V-I polarization curve for a single-cell fuel cell is shown in Fig. 2.1, where the reduction of the fuel cell voltage with load current density can be observed. This voltage reduction is caused by three major losses [7-9]. At low current densities, the dominant loss is the activation loss, which is caused by the slowness of the reactions taking place at the electrode surface. The voltage drop created by the activation loss is highly non-linear.

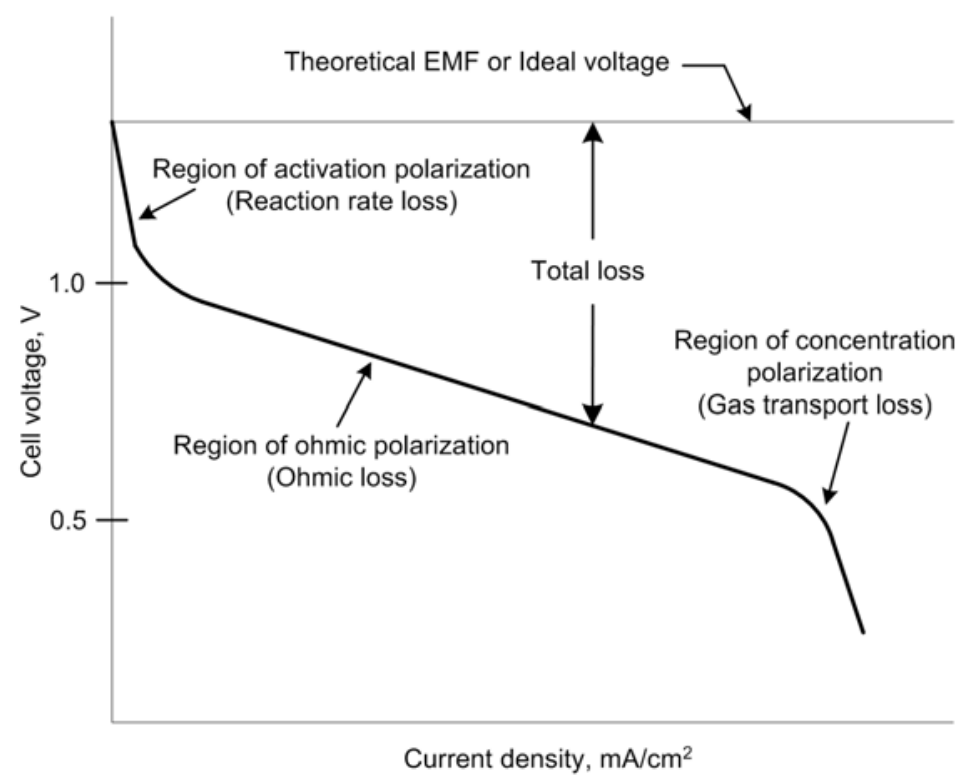

Fig. 2.1. Theoretical V-I polarization curve of the fuel cell used in the calculations.

Ohmic losses are caused by the flow of electrons through the electrolyte and through the electrodes. The electrolyte should transport ions only through the cell; however, a small amount of fuel diffusion and electron flow occurs. Ohmic losses are essentially linear, i.e. proportional to the current density. Decreasing the electrode separation and enhancing the ionic conductivity can reduce the ohmic losses.

The final cell loss mechanism is the gas transport loss. Gas transport losses occur throughout the V-I curve and increase in relative contribution at higher current densities. For SOFCs, significant gas transport losses occur at higher current densities when the water $\left(\mathrm{H}_{2} \mathrm{O}\right)$ product interferes with $\mathrm{H}_{2}$ and carbon monoxide (CO) reactant flow through the porous microstructure of the fuel electrode (anode). The output voltage decreases with the decrease in the reactant concentration. 
Figure 2.2 shows the static characteristics of a $10 \mathrm{~kW}$ SOFC module. Static characteristics of single-cell SOFCs were obtained from spreadsheet models produced by the Pacific Northwest National Laboratory (PNNL) [10]. To get the necessary voltage and power output ratings, several of these cells were stacked in series and parallel. The resulting V-I curve in the figure shows a noload voltage of $\mathrm{V}_{\mathrm{fc}, \mathrm{NL}}=74.2 \mathrm{~V}$ and a full-load $(233 \mathrm{~A})$ voltage of $\mathrm{V}_{\mathrm{fc}, \mathrm{FL}}=42.91 \mathrm{~V}$. The results presented in this report utilize these characteristics for calculations.

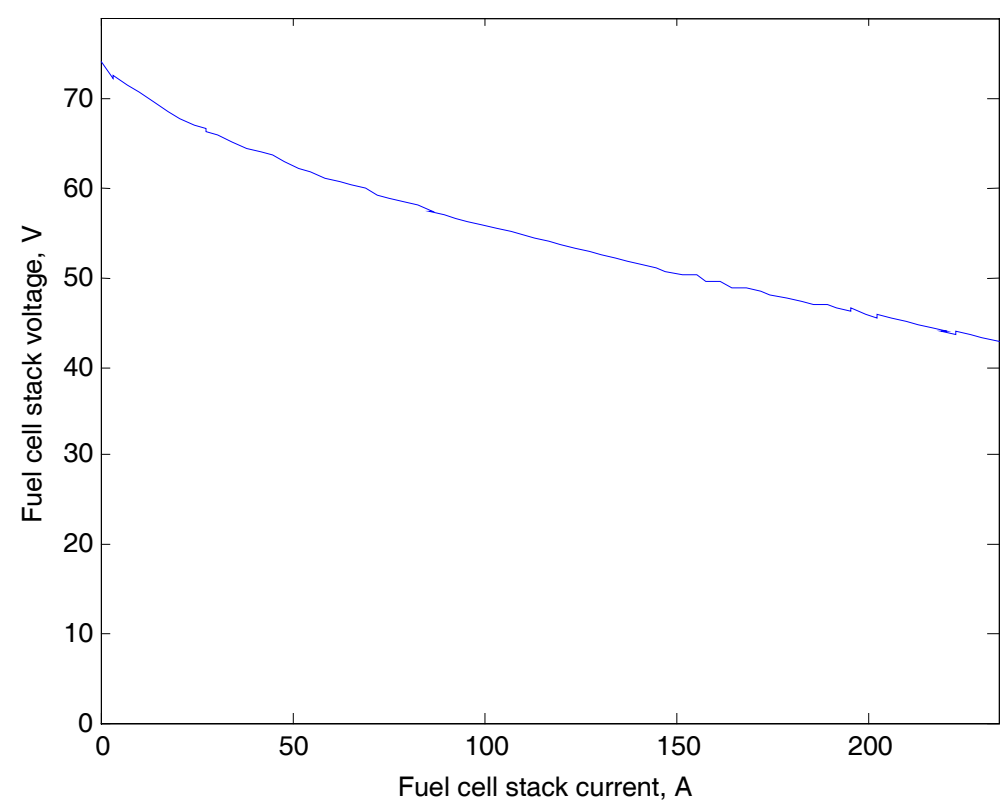

Fig. 2.2. Polarization curve for a $10 \mathrm{~kW}$ solid oxide fuel cell module.

\subsection{FUEL CELL POWER ELECTRONICS INTERFACE}

Today, there is not yet a standard rating for the output voltage of a fuel cell. Present fuel cell stack modules are typically producing direct current (DC) voltages of between 20 and $50 \mathrm{~V}$ at full-load. The DC power must be inverted and conditioned through power electronic devices to produce appropriate AC grid-level voltages. As shown in Fig. 2.3, a DC-DC boost converter is required to boost the input voltage level for the inverter. This boost converter, in addition to boosting the fuel cell voltage, regulates the inverter input voltage and isolates the low- and highvoltage circuits. The inverter for a residential application is either single- or dual-phase. 


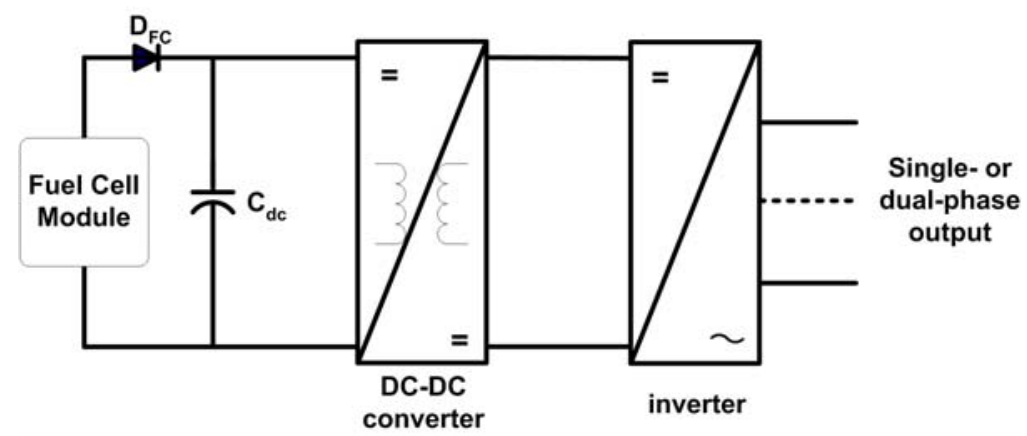

Fig. 2.3. Typical fuel cell power electronics interface block diagram.

Figure 2.4 shows the circuit diagram of a basic DC-DC boost converter. This converter does not have isolation. If electrical isolation is required, then a circuit similar to the one in Fig. 2.5 would be more appropriate. The transformer in this circuit isolates the primary circuit from the secondary and boosts the voltage.

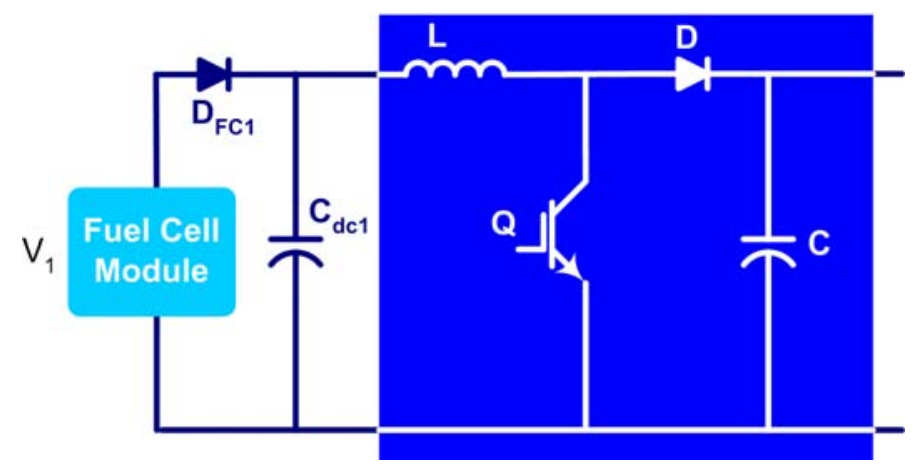

Fig. 2.4. Typical DC-DC boost converter.

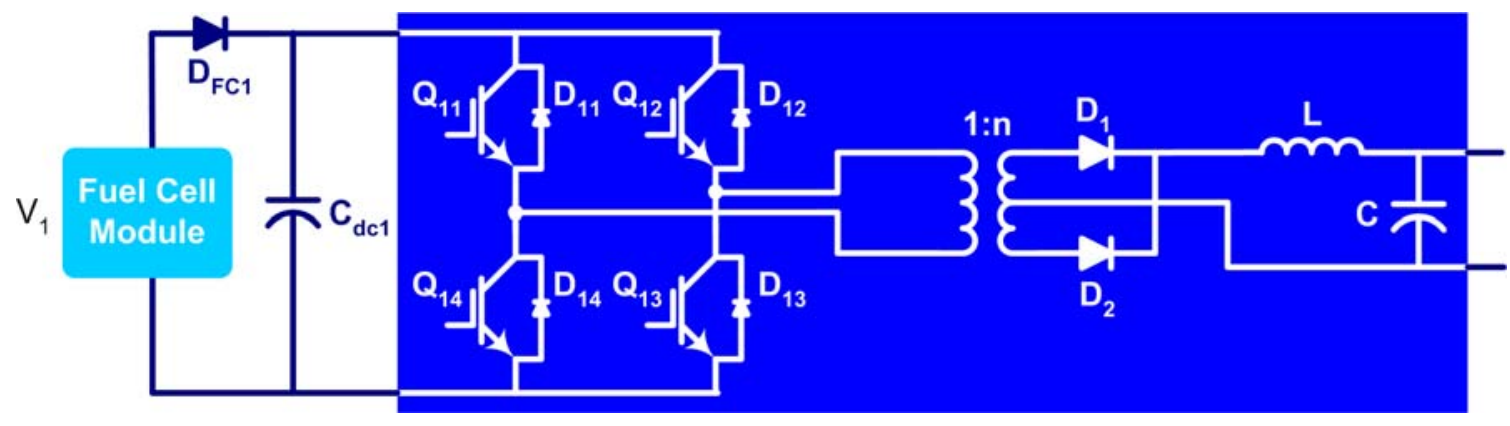

Fig. 2.5. Isolated DC-DC boost converter.

When a power electronics interface is being designed for a fuel cell system, there are other concerns related to fuel cell output current. Fuel cell systems, typically, cannot sink currents; therefore, the power converter should be designed accordingly. A diode at the output of a fuel cell would help prevent current into the fuel cell module. Another concern is the converter input ripple current, which must be kept at a minimum for a healthier fuel cell operation. 
This report focuses on high power applications where several low-power (3-10 kW) fuel cell modules are available and have to be connected together. There are several options to aggregate them using power electronics: series, DC-link, high-frequency AC- (HFAC-) link, or multilevel architectures. More information on these architectures is given in the next section. The easiest approach would be the series architecture since it does not contain any power electronics; therefore, this architecture will be taken as a base case against which to compare other more novel cases.

\subsection{OTHER POWER CONVERTER ISSUES}

When designing a power electronics interface for a fuel cell system, several factors specific to fuel cells have to be considered. These factors are listed in the following subsection with brief descriptions. Some additional factors and recommendations will be given at the end of the report.

\subsubsection{Regeneration}

Fuel cells, with the exception of reversible fuel cells, cannot accept any current feedback; therefore, to make sure that regeneration into the fuel cell does not happen, a series diode is inserted at the fuel cell output (Fig. 2.5). If some regeneration is required, then a capacitor at the output of the fuel cell after the diode can be used to accept the current.

\subsubsection{Fuel Cell Dynamic Response}

The dynamic response of a fuel cell is much slower (on the order of seconds) than the dynamic response of a power converter. To handle the fast transients of a power converter, a capacitor at the fuel cell output is required (Fig. 2.5).

\subsubsection{Input Ripple Current}

Fuel cells want to feed pure DC loads; however, power converters switch at high frequencies and draw ripple currents from their source. A capacitor at the fuel cell output could filter some of this ripple. To better filter the ripple, a larger capacitor might be required, which increases the size and reduces the reliability of the power converter. A National Energy Technology Laboratory (NETL) study [11] reports that the ripple frequencies above $400 \mathrm{~Hz}$ have minor impact on the fuel cell operation. It also recommends that the fuel cell inverters have a ripple factor of less than $4 \%$. 
Input current ripple concern may soon be negated with the recent research results. High frequency ripple is readily negated through the cascading and interleaving of the DC-DC switching devices. Under the SECA Core Technology Program, the Virginia Polytechnic Institute and State University recently demonstrated the ability to cancel both low and high frequency ripple through control of device switching in a DC-DC converter. The added capability to actively nullify low frequency $(120 \mathrm{~Hz})$ ripple is significant because technology development eliminates the need for capacitors to filter low frequency ripple. Consequently, cost, weight, volume and service life and should be considerably enhanced.

\subsubsection{Isolation}

Converter isolation is required if there is a great voltage difference between the fuel cell voltage and the output of the converter. This isolation is usually provided by the transformer in a DC-DC converter. A transformer between the inverter and the grid might also be required so that the grid will be protected from any possibility of a DC offset at the output of the inverter.

\subsubsection{Stack Voltage Variation}

The fuel cell stack voltage varies with load current as shown in Fig. 2.2. The voltage at no load could be twice that at full load; therefore, when power converters for fuel cells are being designed, this voltage variation has to be taken into account. 


\section{POSSIBLE ARCHITECTURES}

To aggregate numerous SOFC modules, five different approaches were studied for this report: series, DC distribution, HFAC distribution, cascaded multilevel, and multilevel. Each of these architectures will be described in the following subsections.

\subsection{SERIES ARCHITECTURE}

One way of aggregating fuel cell modules is to connect them in series and connect the output to a power converter as shown in Fig. 3.1. To achieve the required power level, fuel cell modules can also be connected in parallel. Note that in paralleling fuel cell modules, extreme caution should be taken, since it is undesirable to feed current to the cells (unless a reversible fuel cell module is involved); a diode should be inserted as shown in Fig. 3.2 to block any possible circulating currents between the fuel cell modules.

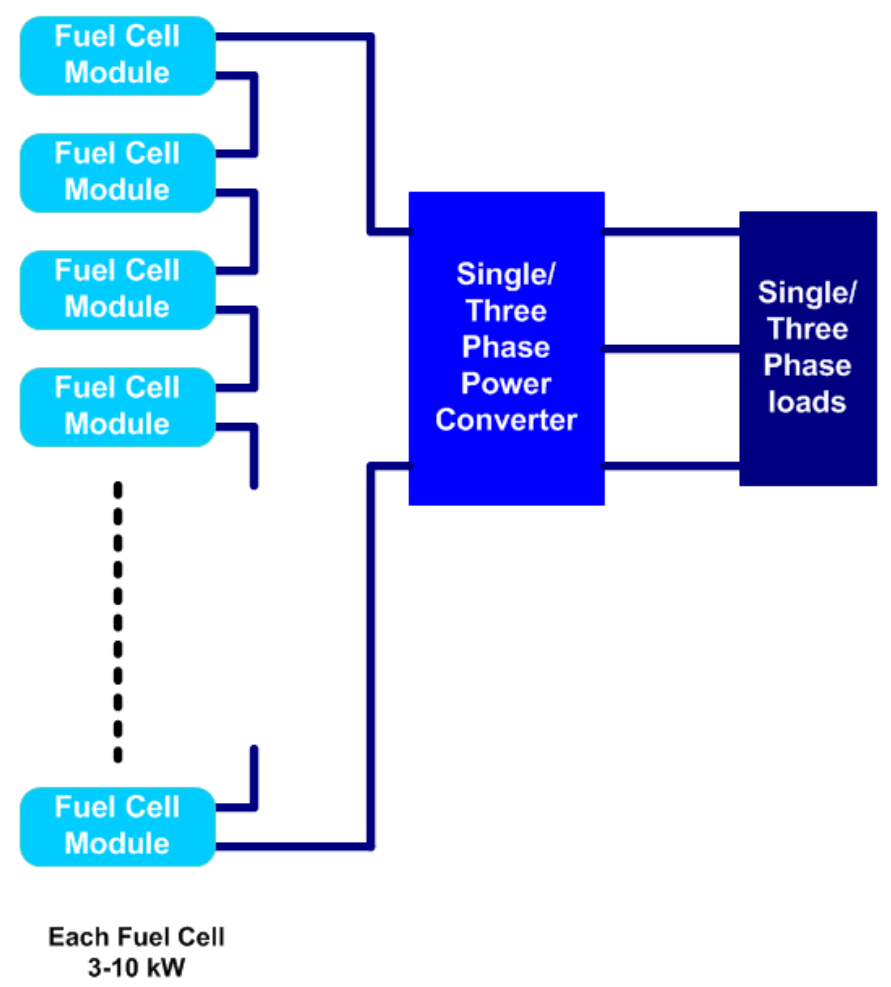

Fig. 3.1. Block diagram of the series architecture. 


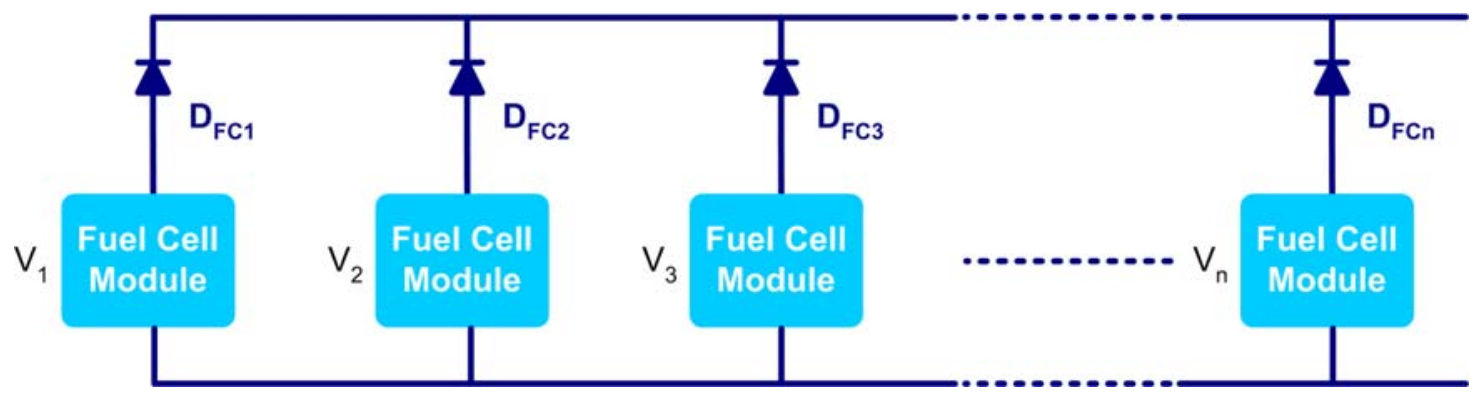

Fig. 3.2. Parallel architecture.

The fuel cell modules shown in Fig. 3.1 are connected in a series architecture to a power converter, which can be either a single-phase or a three-phase inverter as shown in Fig. 3.3 or a DC-DC converter before the inverter as depicted in Fig. 3.4. Both of these cases are explored in the next sections.

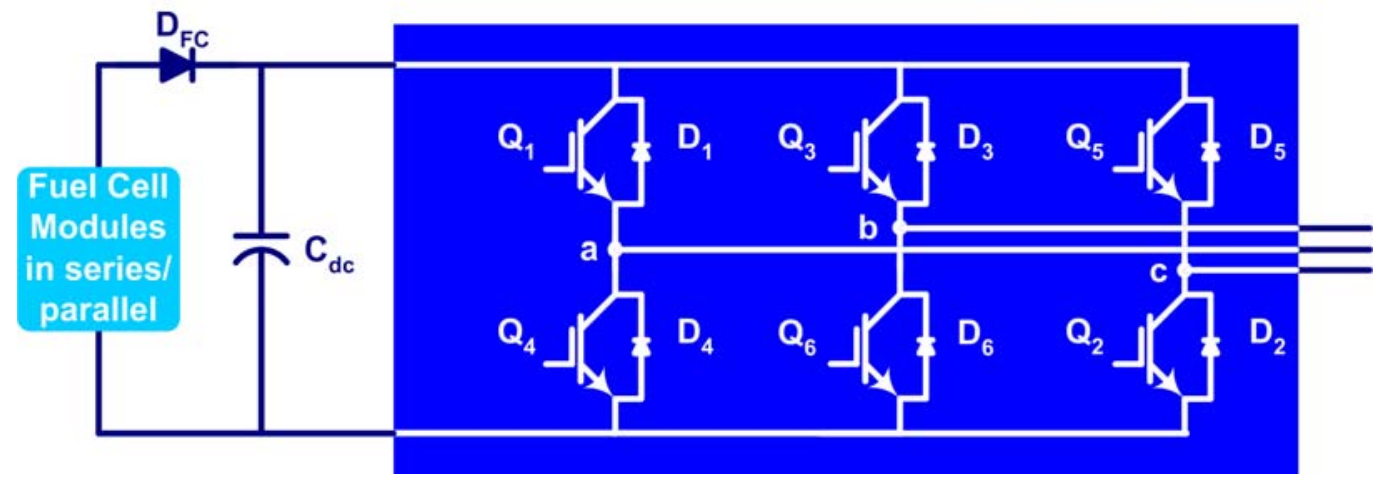

Fig. 3.3. Case A - Series architecture with three-phase inverter.

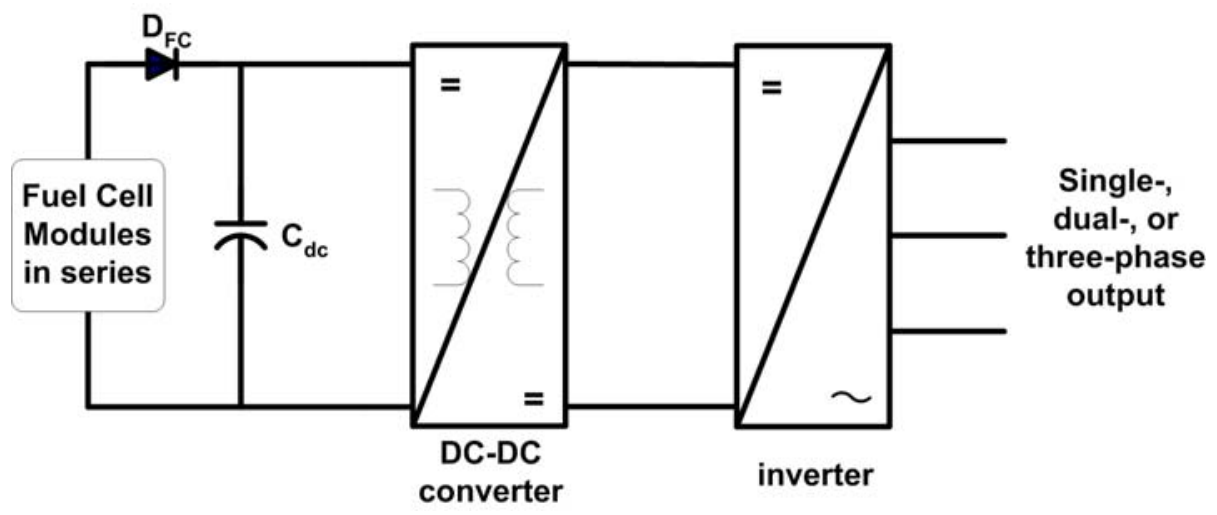

Fig. 3.4. Block diagram for Case B.

\subsubsection{Case A - Series Architecture with Three-Phase Inverter}

In this approach, fuel cell modules are connected in series and fed to an inverter as shown in Fig. 3.3. This approach is similar to the single-module power electronics interface shown in Fig. 2.3 but without the DC-DC converter. Since the cumulative fuel cell module output voltage 
in this case is enough ( $>400 \mathrm{~V}$ ) for the inverter to produce AC grid level voltages, there is no need for a voltage boost.

The problem with this approach is that the fuel cell voltage varies with load current; it is low at full load and much higher at no load as shown in Fig. 2.2.

Assuming that the inverter needs a minimum DC-link voltage, $\mathrm{V}_{\mathrm{DC}}$, then the number of fuel cells required to obtain $\mathrm{V}_{\mathrm{DC}}$ at full load can be found by

$$
n_{\text {total }}>\frac{V_{D C}}{V_{f c, F L}},
$$

where $n_{\text {total }}$ is the number of fuel cells required and is an integer, and $V_{\mathrm{fc}, \mathrm{FL}}$ is the voltage of a fuel cell module at full-load.

A three-phase inverter running at the border of the linear pulse-width modulation (PWM) region with a modulation index of 0.785 requires $396.2 \mathrm{~V}$ DC-link voltage to produce 220 Vrms. Considering that $\mathrm{V}_{\mathrm{fc}, \mathrm{FL}}=42.91 \mathrm{~V}$ (Fig. 2.2), the minimum number of fuel cell modules required to produce this DC voltage is

$$
n_{\text {total }}>\frac{V_{D C}}{V_{f c, F L}}=\frac{396.3 \mathrm{~V}}{42.91 \mathrm{~V}}=9.23 .
$$

Since $\mathrm{n}_{\text {total }}$ is an integer, $\mathrm{n}_{\text {total }}=10$. Then, at full-load, $\mathrm{V}_{\mathrm{DC}}=429.1 \mathrm{~V}$.

Now consider the no-load operation. This fuel cell has a no-load voltage of $\mathrm{V}_{\mathrm{fc}, \mathrm{NL}}=74.2 \mathrm{~V}$; thus, at no-load, $\mathrm{V}_{\mathrm{DC}, \mathrm{NL}}=742 \mathrm{~V}$, an excess of $345.7 \mathrm{~V}$ above the voltage needed for the DC-link of the inverter.

For a DC-link voltage of $396.2 \mathrm{~V}, 600 \mathrm{~V}$ inverter switches would be barely suitable because of the significant voltage range on the fuel cell stack (396 to $742 \mathrm{~V}$ ). However, because of the high no-load voltage (742 V) of the fuel-cell modules, in this case, $1200 \mathrm{~V}$ switches are required. As of October 2004, the $1200 \mathrm{~V}$ insulated gate bipolar transistors (IGBTs) are about $70 \%$ more expensive than $600 \mathrm{~V}$ IGBTs for the same current rating.

In general operation, the inverter expects a constant DC-link voltage ( $\left.\mathrm{V}_{\mathrm{DC}}\right)$; but with voltage sensors on the DC-link and some modification of the inverter control system, it can also operate with variable DC-link voltage if the modulation index is varied with DC-link voltage. 


\subsubsection{Case B - Series Architecture with Three-Phase Inverter and DC-DC Voltage Regulator}

This case is similar to the architecture in Fig. 2.3, with multiple fuel cell modules in series replacing the single fuel cell module (Fig 3.5). When ten or more fuel cell modules are used, the voltage supplied by the fuel cells is higher than what the DC-link needs; therefore, there is no need for boosting the voltage. In addition, since there is not much difference in the low-voltage and high-voltage portions of the circuit, the isolation is not essential. The most important role of this converter is to regulate the DC-link voltage so that it stays constant at $396.2 \mathrm{~V}$ in this case.

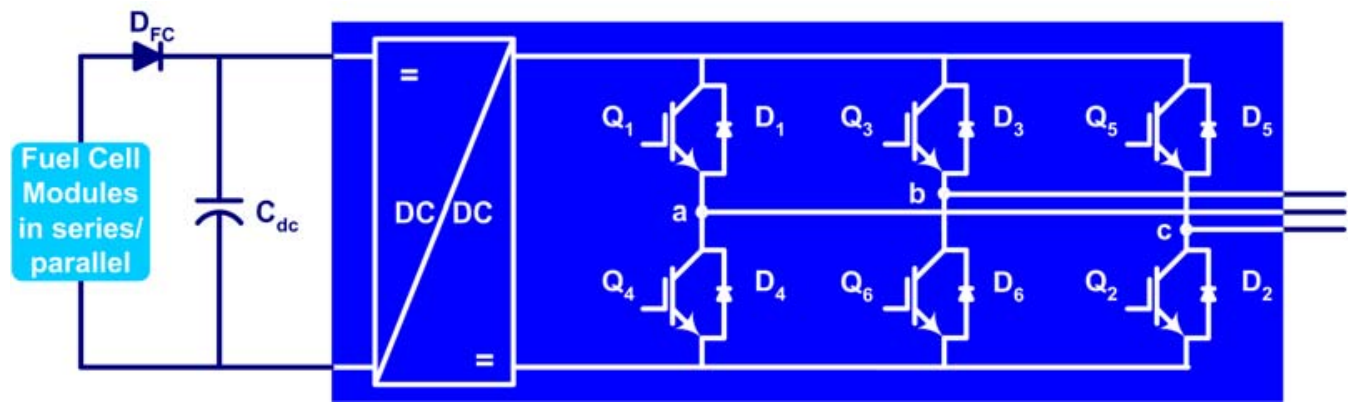

Fig. 3.5. Case B - Series architecture with DC-DC voltage regulator and a three-phase inverter.

Note that, in applications where fewer fuel cell modules are required, the DC-DC converter might have to buck and/or boost, depending on the cumulative fuel cell output voltage, isolation might then be more important.

\subsubsection{Comparison}

The difference between these cases is that in Case B, the inverter sees a constant DC voltage, while in Case A, the inverter sees the cumulative fuel cell module voltage varying with the load current. Note that without a DC-DC converter, the power switches in Case A have to be rated for higher voltages because at low loads the fuel cells will supply high voltages. When a DC-DC converter is used, as in Case B, however, this is not a problem and the power switches can be rated at the required fixed DC-link voltage.

There are some trade-offs between these two options. One of them is that in Case A, the inverter switches have to be rated higher; therefore, the inverter will be more expensive. In Case B, the inverter will have a lower voltage rating and will be cheaper; but the DC-DC converter will add to the device count, the power electronic device energy losses, and the converter expense. Moreover, if higher-voltage switches are operated at lower voltages, their efficiency will suffer because higher voltage switches have voltage drops and consequently higher conduction losses. 
The second trade-off concerns the control system. Without a DC-DC converter, the inverter control complexity increases to accept varied input voltage; but the additional DC-DC converter also adds to the control complexity.

\subsubsection{Advantages and Disadvantages}

The advantages for series architectures Cases A and B are these:

- The fuel cell modules are connected in a simple series connection.

- The device count is low: only six power switches are required when no DC-DC regulator is used and sufficient fuel cell modules are aggregated.

- Three-phase inverter modules are commonly used and thus are inexpensive. Highervoltage-rated switches that need to handle no-load voltage levels would be more expensive.

- This is a modular architecture consisting of fuel cell modules, an inverter module, and a DC-DC converter module.

The disadvantages for series architectures Cases A and B are these:

- If one fuel cell fails in Fig. 3.1 (open circuit), the system will not work. The failing unit has to be replaced or bypassed externally. This causes reliability concerns.

- The DC-DC converter or inverter power switches have to be derated, depending on which case is being used.

\subsection{CASE C - DC BUS DISTRIBUTION ARCHITECTURE}

To overcome the disadvantages of the series architecture, a step-up DC-DC converter can be connected to each fuel cell module; and the constant DC outputs of these converters can be connected in parallel, producing the DC bus distribution architecture shown in Fig. 3.6.

In this architecture, each fuel cell module has its own power converter module. These DC-DC converters can be of the boost type if the fuel cell module voltage is less than the DC bus distribution voltage. The fuel cell module voltage can be equal to or greater than the DC bus distribution voltage if a sufficient number of cells are stacked together to form the fuel cell module. For such a scheme, a DC regulator should suffice to control the DC bus distribution voltage at a value best suited for the inverter. 


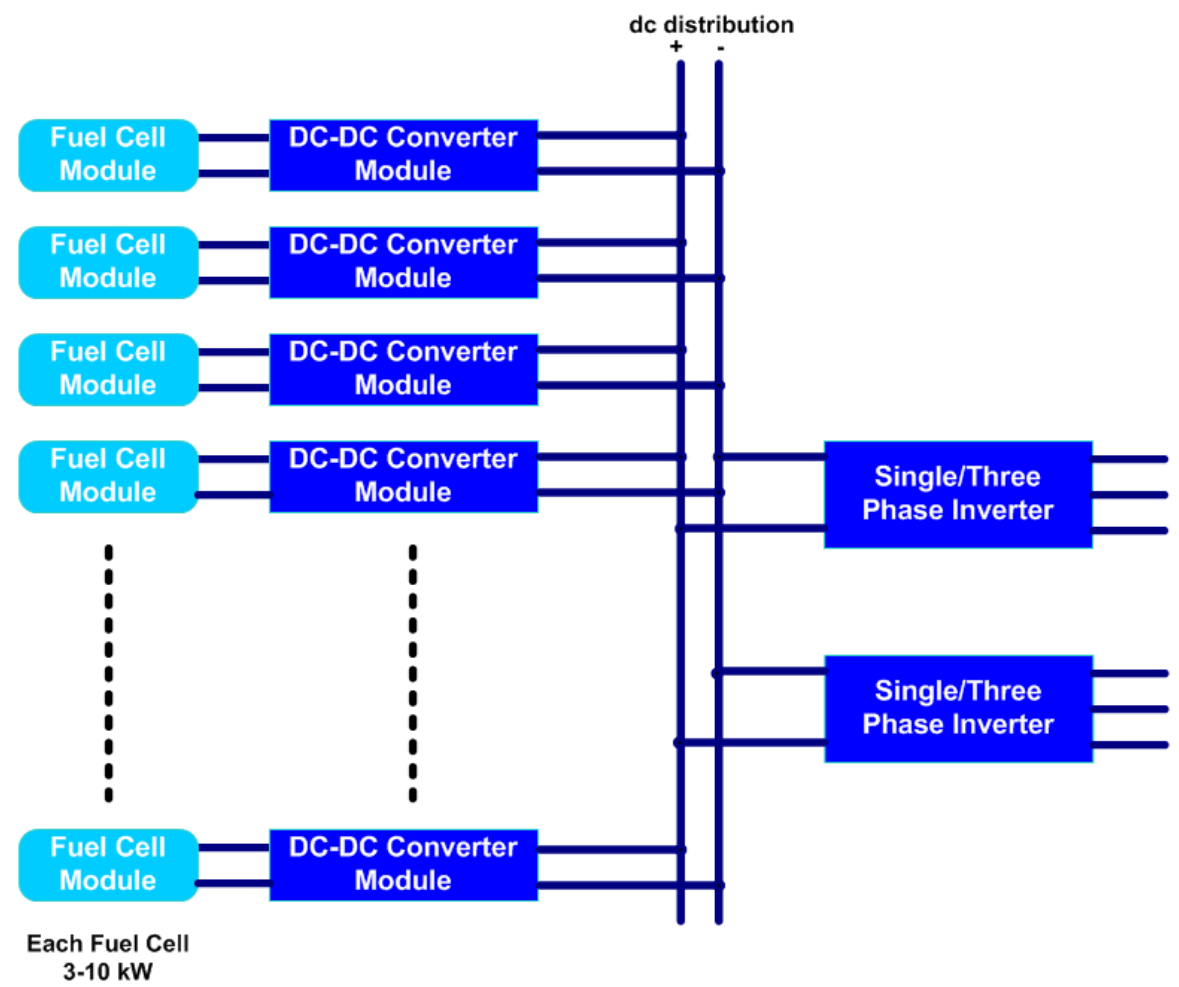

Fig. 3.6. Block diagram of the DC bus distribution architecture.

To increase reliability, a redundant number of fuel cells can be connected in this architecture. Additionally, the constant voltage DC-link can also be used to feed one or several inverters, depending on the application.

Typical DC-DC converters for this application would be like the ones shown in Figs. 2.4 and 2.5, and the typical inverter would be like the one in Fig. 3.5 for a three-phase case.

The advantages of the DC Bus distribution architecture are these:

- Each fuel cell can be controlled independently with the DC-DC converter module. The fuel cell modules can even be disconnected from the system for maintenance or replacement, and the rest of the system will continue the operation.

- Increased availability and fault-tolerant operation can be achieved by adding redundant fuel cell modules together with DC-DC converter modules. This architecture enhances the availability of fuel cell power, albeit at a reduced capacity while a fuel cell module is off-line for service or replacement. 
- Each subsystem can be designed as an individual module, and they can be combined as needed. The list of modules would include the fuel cell module, the DC-DC converter module, and the inverter module. The inverter is already commercially available in a module.

The disadvantages of the DC Bus distribution architecture are these:

- When the instantaneous voltages at the outputs of the DC-DC converters are not equal, circulating currents will occur. These will interfere with the operation of the system; therefore, they have to be prevented. Therefore, more complex control algorithms are required.

- This architecture requires a higher device count than the series architecture because of the DC-DC converters, but the devices have lower power ratings because more devices will be sharing the load current.

\subsection{CASE D - HFAC DISTRIBUTION ARCHITECTURE}

Each fuel cell module is connected to an H-bridge inverter (Fig. 3.7), which converts the DC input to HFAC voltage, typically at more than $20 \mathrm{kHz}$. This AC voltage most commonly can be either a sine wave, a square wave, or a square wave with zero intervals. It is fed to a high frequency transformer (Fig. 3.8), which can boost the voltage if required. The secondary of this transformer is connected to one or several single-phase-to-three-phase cycloconverters or matrix converters, which convert the HFAC voltage to lower-frequency AC voltage (like $60 \mathrm{~Hz}$ ). Typical single-phase-to-three-phase cycloconverter/ matrix converter circuit diagram utilizing AC switches is shown in Fig. 3.9.

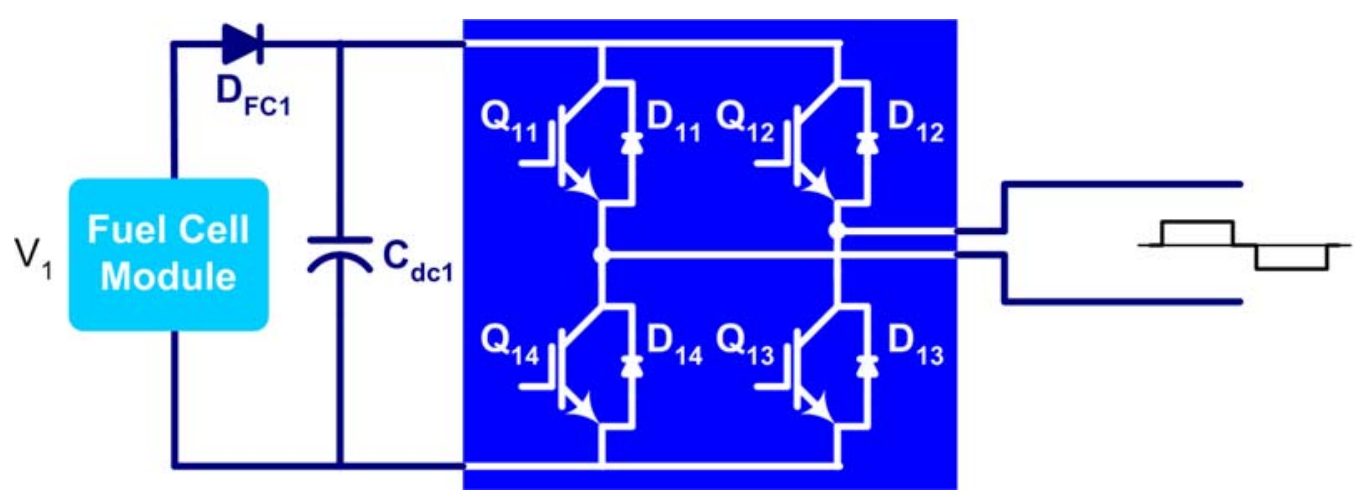

Fig. 3.7. Typical H-bridge inverter. 


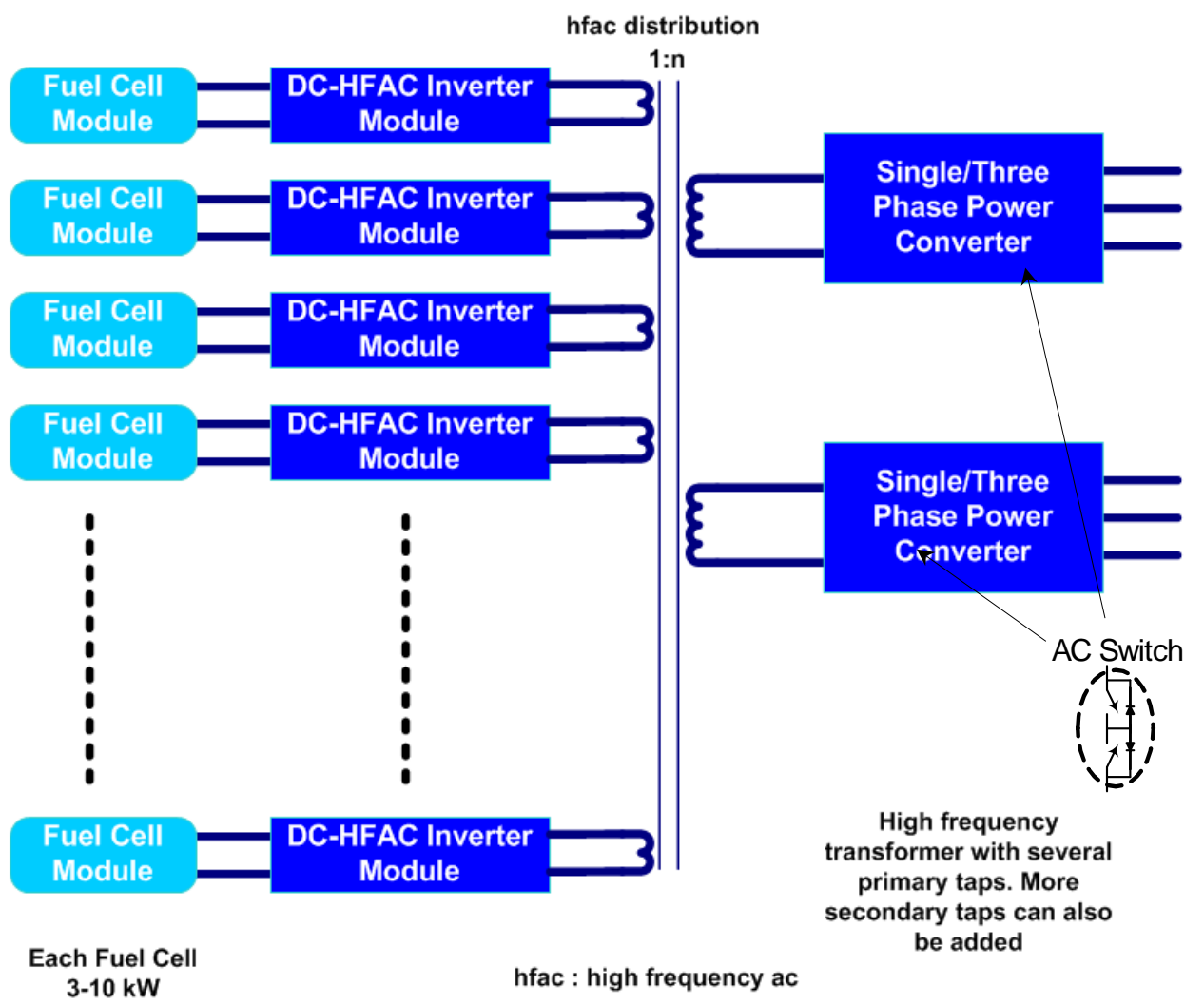

Fig. 3.8. Block diagram of the HFAC distribution architecture.

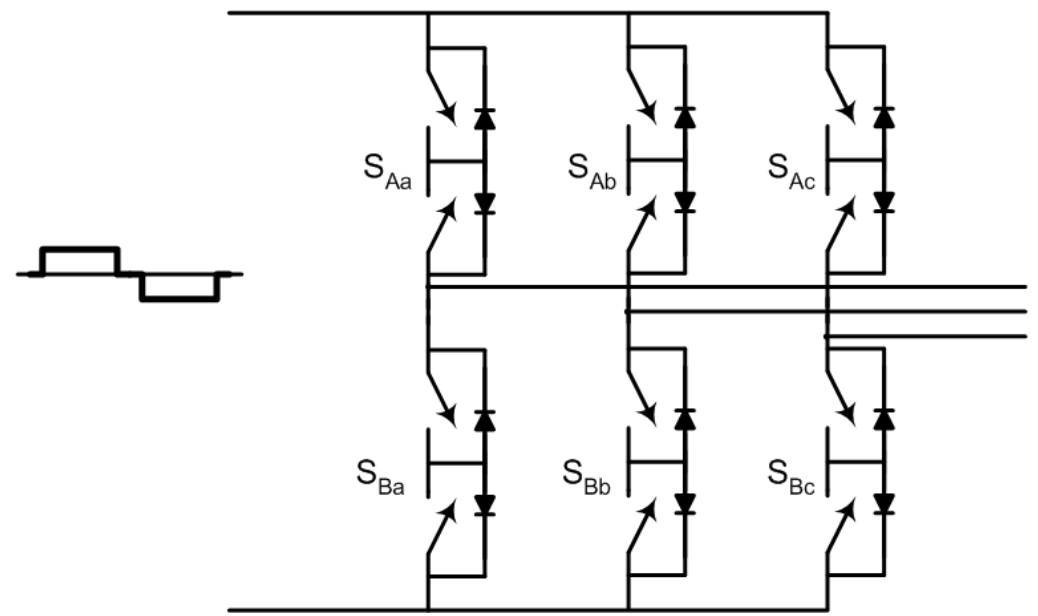

Fig. 3.9. Typical single-phase to three-phase matrix converter.

The transformer brings the advantages of isolation, voltage boost, and the capability to add other power sources and loads through a power converter. As seen in Fig. 3.8, several converters can be connected to the extra primary and secondary taps, and the power can flow in different directions as required by the application. 
This HFAC transformer is much smaller than a typical bulky $60 \mathrm{~Hz}$ transformer. As the frequency increases, the size of a transformer decreases. A $42 \mathrm{kVA} 20 \mathrm{kHz}$ transformer weighs just a few pounds and has roughly cubic dimensions with $12 \mathrm{~cm}$ per side.

The challenge of fuel cell voltage variation with load also exists for the HFAC architecture. One solution to this problem is to insert a voltage regulator between fuel cell module and the DC-HFAC inverter. Another solution involves monitoring fuel cell voltages and modifying the control signals accordingly.

The advantages of the HFAC distribution architecture are these:

- Because of the high-frequency operation, the harmonics are at higher orders and it is easier to filter them with smaller, less-costly filters.

- The passive components required at high frequencies are smaller and lower cost just as in the case of the transformer.

- Modularity is similar to the DC distribution case.

The disadvantages of the HFAC distribution architecture are these:

- The HFAC transformer has to be specially designed; therefore, it will be expensive.

- If the transformer input voltage has a DC component, there will be a problem of transformer saturation. This can be eliminated with feedback control.

- Cycloconverters and matrix converters require AC switches, which are two switches connected back-to-back as shown in Fig. 3.8. They are not commonly available as modules.

- The control is complex because of the cycloconverter/matrix converter control and its interaction with the H-bridge high frequency inverters.

\subsection{CASE E - CASCADED MULTILEVEL ARCHITECTURE}

Instead of connecting the fuel cell module and the power converter pairs in parallel as in the DC distribution case, they can be connected in series to form a cascaded multilevel converter as shown in Fig. 3.10.

There are many multilevel converter architectures available [12]. Among these, cascaded multilevel converters are distinct in the sense that they are more modular than the rest, and the input sources are isolated from each other. That is why, in this report, cascaded multilevel converters have been classified as a unique architecture compared to other multilevel converters. 


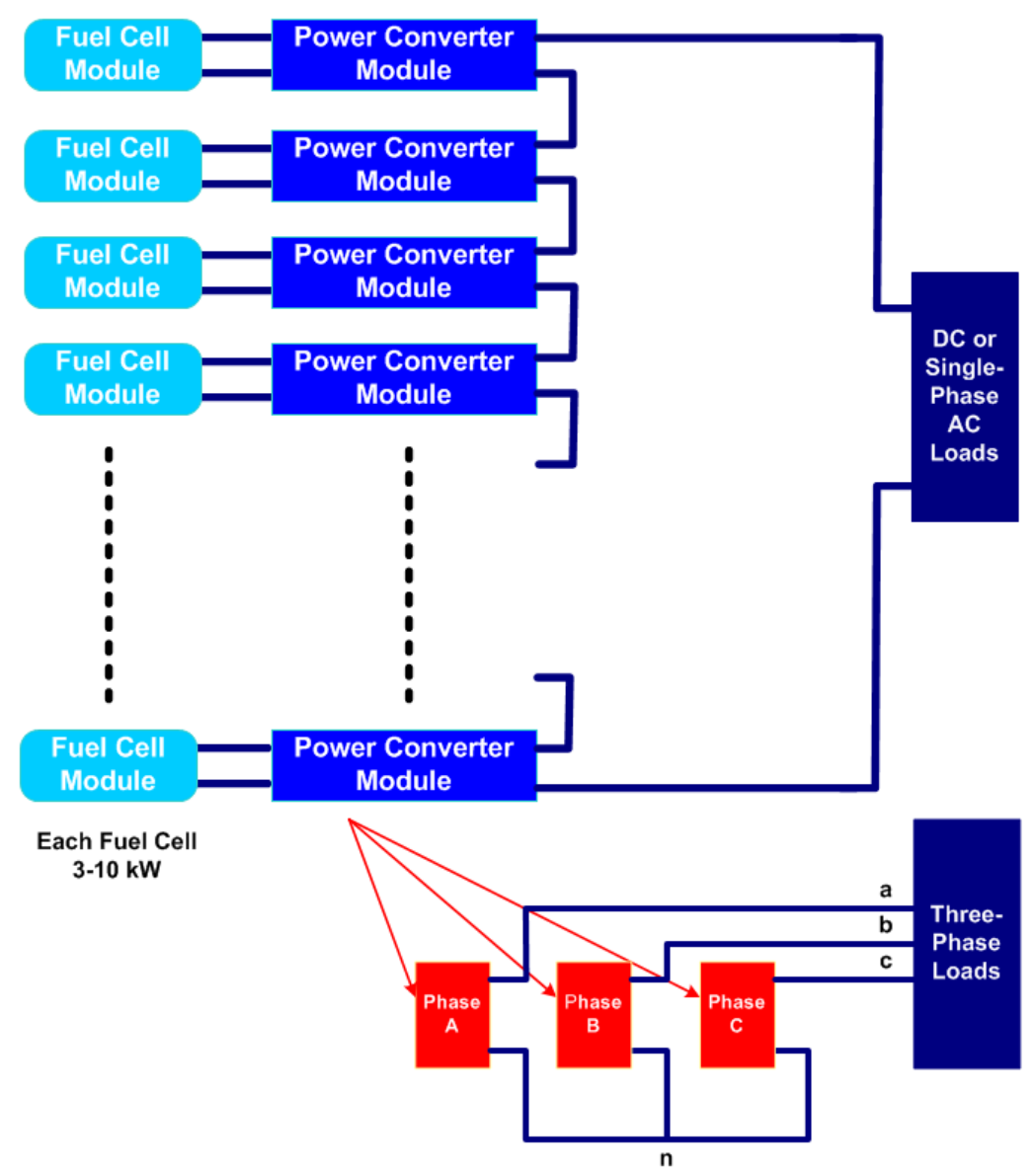

Fig. 3.10. Block diagram of the cascaded multilevel architecture.

A cascaded multilevel converter consists of a series connection of several pairs of fuel cell and power converter modules. If all the power converters are inverters, then the resulting system is a single-phase multilevel inverter. Three of these single-phase inverters can be connected in wye or delta to produce three-phase multilevel inverter systems. A seven-level cascaded multilevel inverter circuit diagram is shown in Fig. 3.11.

Each H-bridge converter produces a pseudo square wave with zero intervals at different duty ratios. At the output of the converter, these voltages are summed to get a stepped output voltage as shown in Figs. 3.11 and 3.12. Three of these single-phase voltages can be connected to form a three-phase supply as shown in Fig. 3.10.

The power converter module can also be a DC-DC converter, in which case the architecture would be a multilevel DC-DC converter that can be fed to either DC loads or a three-phase inverter to produce three-phase AC voltages, as shown in Fig. 3.10. 


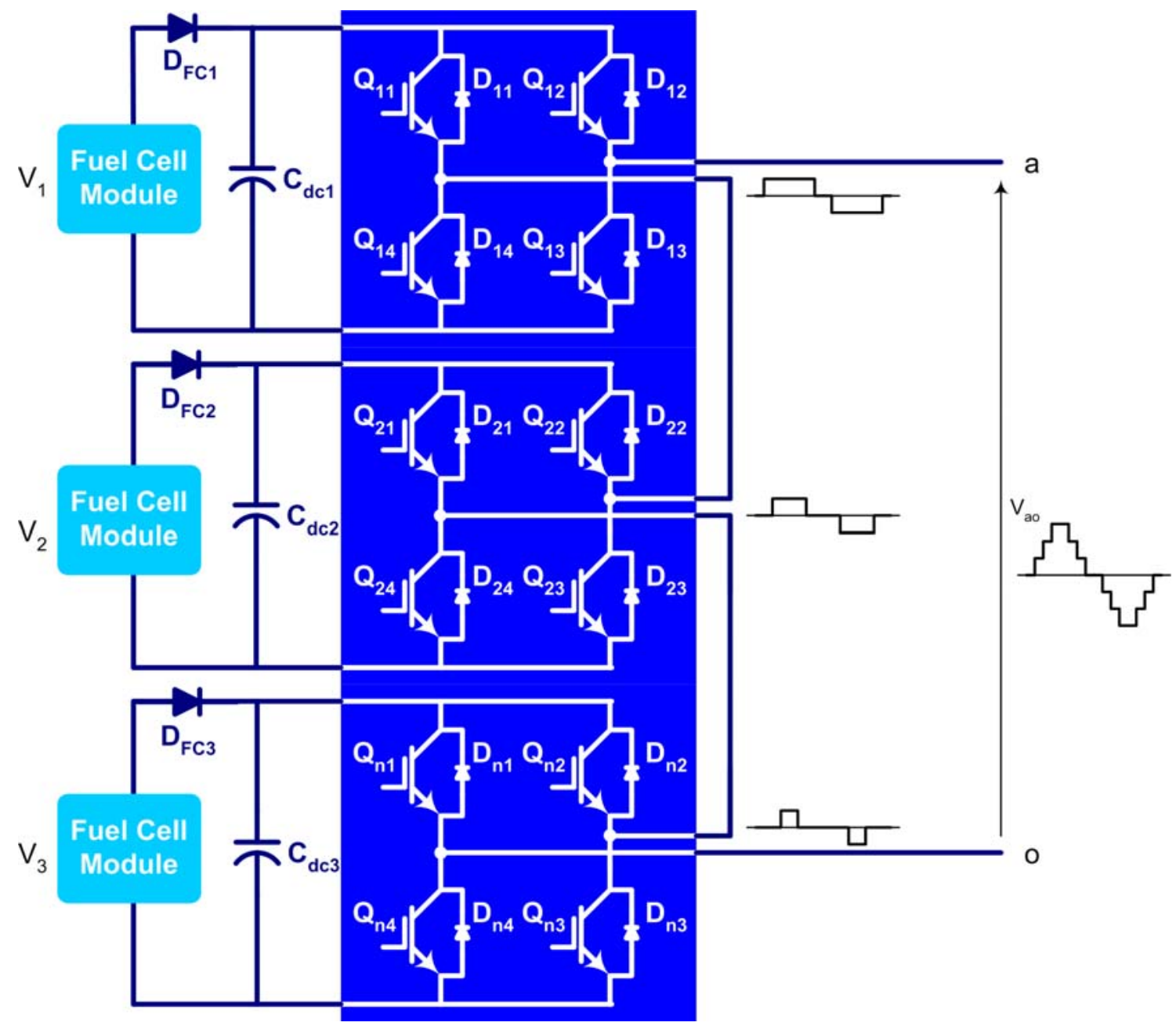

Fig. 3.11. One phase of a cascaded seven-level inverter.

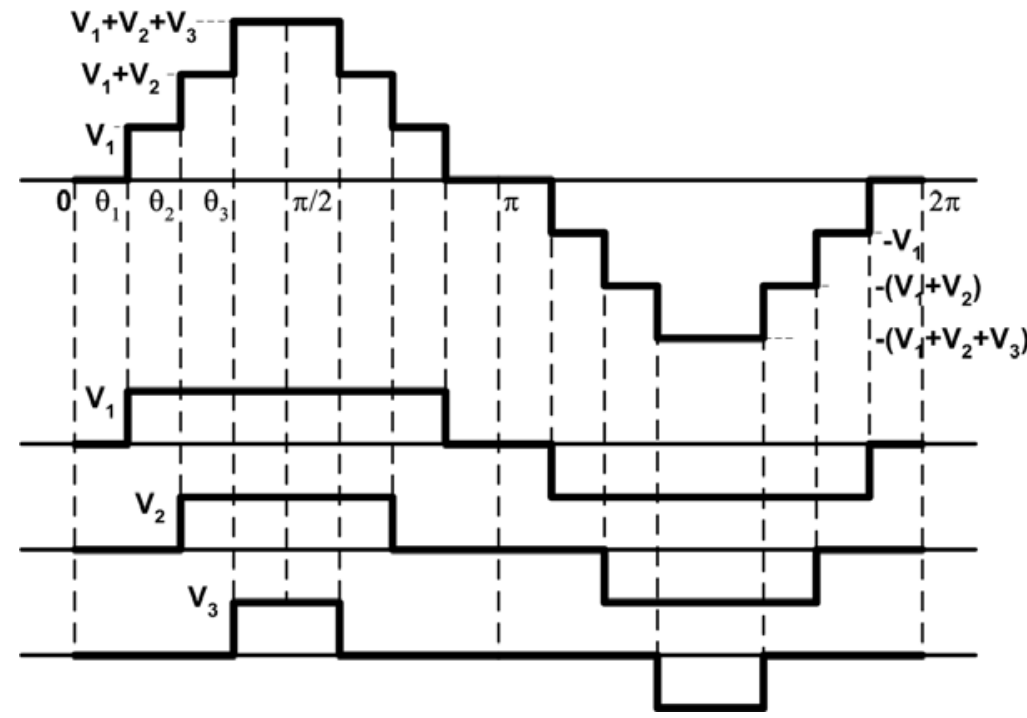

Fig. 3.12. Waveforms of a cascaded seven-level inverter. 
To overcome the fuel cell voltage variation problem, either voltage regulators have to be connected at the fuel cell module output, or fuel cell voltages have to be monitored and the control signals modified accordingly.

The advantages and the disadvantages of cascaded multilevel converters are discussed in the next section.

\subsection{CASE F - MULTILEVEL ARCHITECTURE}

Fuel cell modules can be connected to one single/three-phase multilevel inverter as shown in Fig. 3.13. In this case, there might not be a need for a voltage regulator if fuel cell voltages are monitored.

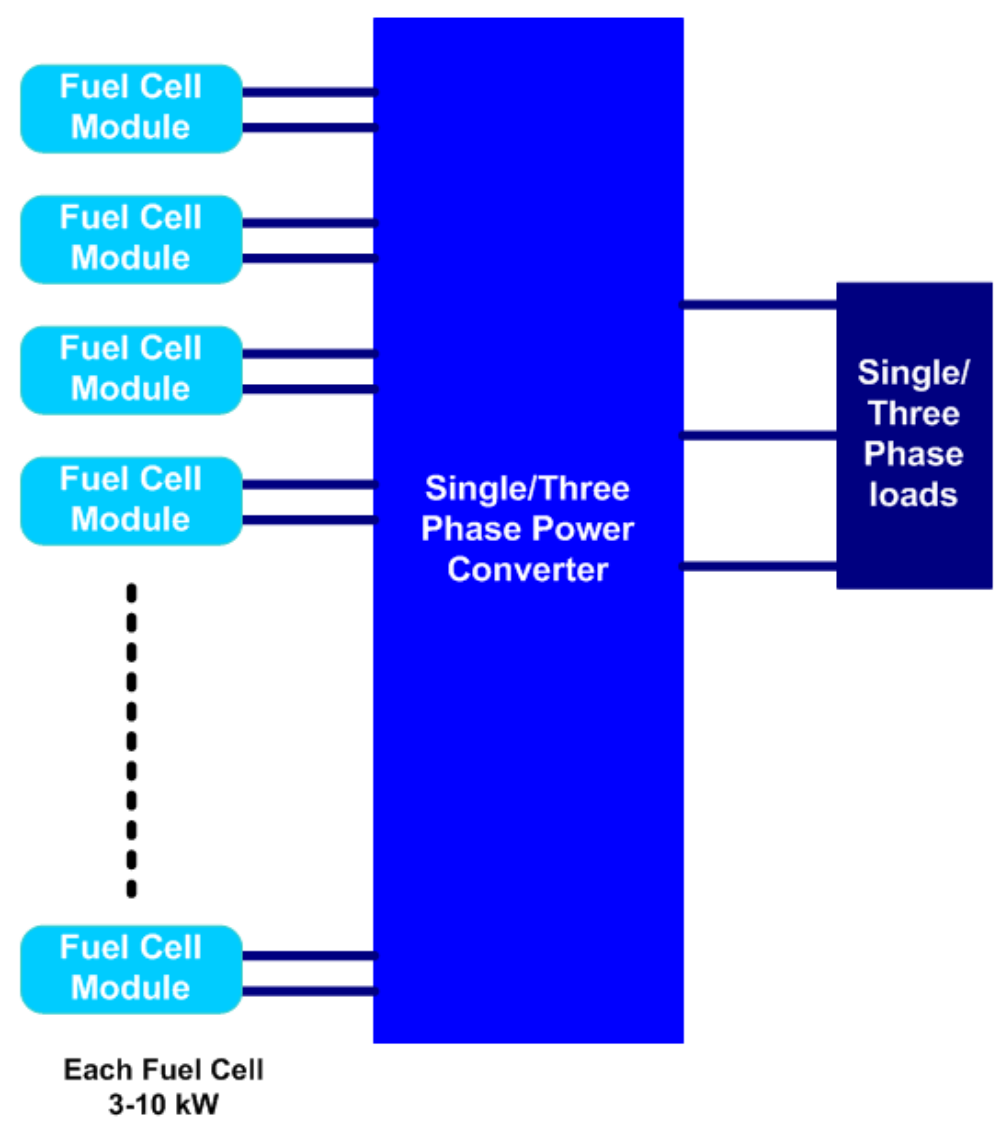

Fig. 3.13. Block diagram of the multilevel architecture.

There are many types of multilevel inverters. One typical multilevel inverter, the diodeclamped multilevel inverter, is shown in Fig. 3.14 for four fuel cell modules.

The stepped output voltage waveform of a multilevel inverter is similar to the one in Fig. 3.12. 
The advantages of multilevel converter architecture are these:

- They are modular, lowering manufacturing costs. The cascaded multilevel converter is more modular than the other multilevel converters.

- Redundant levels can be added for increased reliability.

- Since each phase is built separately from the others, the final converter can be easily connected to be single-phase, multi-phase, or three-phase wye or delta.

- Fundamental frequency switching techniques [13,14] can be applied to decrease the switching losses and to increase the converter efficiency.

- Other control strategies, such as multilevel PWM [15] or multilevel space vector PWM are possible.

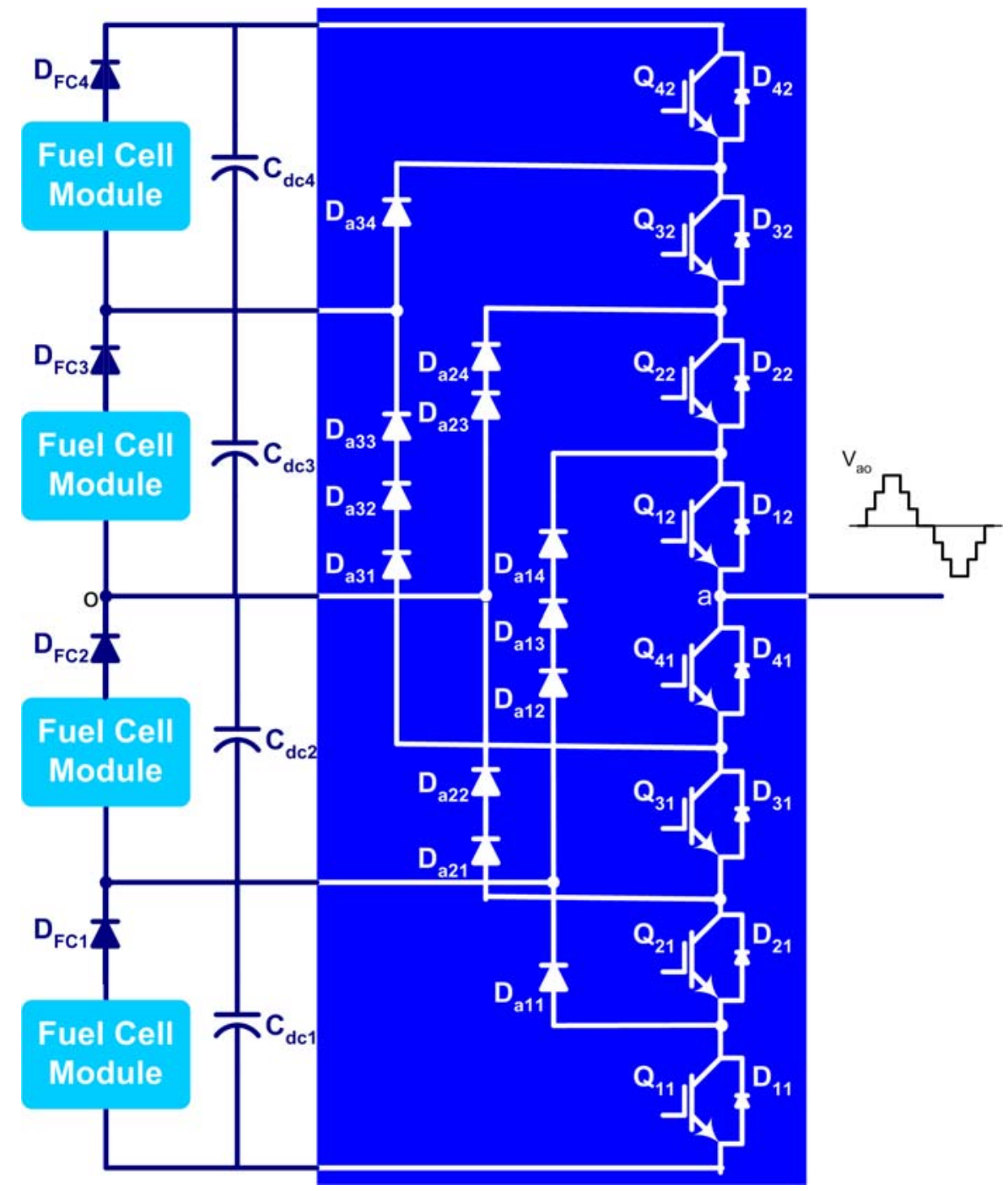

Fig. 3.14. One phase of a diode-clamped seven-level inverter. 
The disadvantages of multilevel converter architecture are these:

- The number of devices used in multilevel converters is high, but the voltage ratings of these devices are lower. An increased number of switches increases the price, but lower-rated switches are less-costly.

- Because of fundamental frequency switching, lower-order harmonics are higher; but there are techniques to reduce these harmonics $[13,14]$. For example, the switching angles can be selected so that the required fundamental voltage is achieved with no $5^{\text {th }}$ or $7^{\text {th }}$-order harmonics. Total harmonic distortion (THD) of $3 \%$ has been achieved using fundamental frequency switching.

- For fuel cell applications, ripple current must be avoided. For a multilevel converter, care must be taken to reduce current ripple. 


\section{COMPARISON MATRIX}

In the previous chapter, five power electronics topologies and their advantages and disadvantages have been discussed. This chapter compares the five topologies with respect to cost (capital and operating), control complexity, reliability, availability (at power system and device levels), fault tolerance, modularity (ability to isolate portions of a system for service or add power generation capacity while other portions of the complete system are still functioning), energy conversion efficiency, and ease of mass customization to enable mass production to drive down costs.

For a better visualization, Table 4.1 provides a matrix in which the topologies are compared in eight categories. Points are given for a topology in each category. The smaller the value is given for a topology, the better the topology is in that category. The following sections will explain how the points are determined.

Table 4.1. The architecture comparison matrix

\begin{tabular}{c|c|c|c|c|c|} 
& A and B & C & D & E & F \\
\hline a & 1 & 3 & 3 & 4 & 5 \\
\hline b & 1 & 3 & 3 & 4 & 5 \\
\hline c & 4 & 2 & 2 & 2 & 3 \\
\hline d & 5 & 1 & 1 & 3 & 3 \\
\hline e & 5 & 1 & 1 & 3 & 3 \\
\hline f & 3 & 1 & 5 & 3 & 4 \\
\hline g & 1 & 3 & 3 & 2 & 4 \\
\hline h & 1 & 2 & 3 & 4 & 5 \\
\hline
\end{tabular}

A and B. Series architecture

C. Cascaded multilevel architecture

D. Multilevel architecture

E. DC bus distribution architecture

F. High-frequency AC (HFAC) distribution architecture

a. Cost (capital and operating): (1-less expensive, 5-more expensive)

b. Control complexity: (1-less complex, 5-more complex)

c. Reliability: (1-more reliable, 5-less reliable)

d. Availability: (at power system and device levels) (1-better availability, 5-worse availability)

e. Fault tolerance: (1-more fault tolerant, 5-less fault tolerant)

f. Modularity: (ability to isolate portions of system for service or add power generation capacity while other portions of the complete system are still functioning) (1-more modular, 5-less modular)

g. Energy conversion efficiency: (1-more efficient, 5-less efficient)

h. Ease of mass customization to enable mass production to drive down costs: (1-easier, 5-more difficult) 


\subsection{COST (CAPITAL AND OPERATING)}

The series architecture costs the least since it requires only a single/three-phase inverter. Among the other architectures, for an aggregation of the same number of fuel cells, the highfrequency distribution costs more than the others because it requires an expensive highfrequency transformer and bi-directional switches to convert the high-frequency voltage of the secondary to $60 \mathrm{~Hz}$. The multilevel architectures have a similar number of switches, and their cost should be lower than that of the DC distribution.

Note that the power switches of the multilevel inverters are of the low-voltage type and cost much less than the full-load switches of the other architectures.

\subsection{CONTROL COMPLEXITY}

The series architecture would have required only a basic control of the inverter if the fuel cell voltages were constant at all times; however, the fuel cell voltage varies with the load current. To produce the required AC output voltage independent of the DC input voltage, the modulation index of the inverter controller has to be varied with DC voltage. This requires only an input voltage feedback.

The other architectures have more complicated controls because they have more switches. Multilevel control with the level reduction technique complicates the control even more at the expense of higher efficiency and higher fuel cell utilization. In addition to the control of many switches in the DC distribution, additional involved control algorithms are required to prevent circulating currents between the DC-DC converters.

The HFAC distribution, on the other hand, has bidirectional switches in the secondary of the HFAC link, which complicate the control of the system. Additional controls are also required to make sure that the HFAC transformer does not saturate.

Considering these points, the series architecture requires the least complex controls. Multilevel architectures without level reduction require additional controls and the complexity of the control increases when level reduction techniques are used. The DC distribution and the HFAC distribution architectures require much more complex controls. 


\subsection{RELIABILITY}

Voltage or current stress on power devices might cause their properties to deteriorate in time. The more power devices a system has, the higher the possibility of failure is and the lower the reliability. For the same number of fuel cell modules, the HFAC distribution architecture would have the most switches. Following HFAC, in order of increasing reliability, would be the DC bus distribution, multilevel, cascaded multilevel, and series architectures.

Reliability with redundancy is investigated in Subsection 4.4.

\subsection{AVAILABILITY (AT POWER SYSTEM AND DEVICE LEVELS)}

Availability addresses the frequency and duration of taking a product out of operation to perform planned maintenance/overhaul tasks. After a fuel cell fault occurs, with necessary precautions, all of the architectures, except the series architecture will continue functioning because the control algorithm will block the switches associated with the malfunctioning fuel cell until a repair is done. The series architecture, however, would require that the fuel cell with the problem be taken out of the circuit and bypassed manually.

For a fault occurring in the power converter, the most available architectures are the multilevel and cascaded multilevel architectures because the converter will continue to operate with a portion of the power circuit not working. The DC bus and high-frequency distribution architectures suffer from a similar problem with their power converters. When a power electronics fault occurs between the fuel cell and the DC bus or HFAC link, the converters will continue providing power to the load. However, if this fault occurs between the load and the DC bus or HFAC link, then the load power will be affected.

When a power electronics failure occurs in the series architecture, load power flow will be affected, making this architecture the least available one.

\subsection{FAULT TOLERANCE}

Following the argument in the previous subsection, the most fault-tolerant architectures are the multilevel and cascaded multilevel. The DC bus distribution and high-frequency distribution architectures are less fault tolerant than both of the multilevel architectures but are better than the series architecture. 


\subsection{MODULARITY}

The modularity classification in this report also includes the ability to isolate portions of system for service or add power generation capacity while other portions of the complete system are still functioning. For safety reasons, the authors of this report do not recommend running the system during maintenance.

In addition to fuel cell modules, all five architectures can be divided into several other modules so that maintenance can be quicker and the number of parts to be stored fewer.

- Series architecture - a DC-DC converter and/or inverter module

- Cascaded multilevel architecture - H-bridge inverter modules

- Multilevel architecture - multilevel inverter module

- DC bus distribution architecture - DC-DC converter and inverter modules

- HFAC distribution architecture - H-bridge inverter, HFAC transformer, and HFACAC converter modules

The most modular architecture is the cascaded multilevel architecture because it needs only H-bridge inverter modules. The series, DC bus, and HFAC distribution architectures are similar in modularity; but the last one requires an additional HFAC transformer. The multilevel distribution requires a multilevel inverter module that is not yet commonly available; and for any number of fuel cells required, there needs to be a whole different level inverter module.

\subsection{ENERGY CONVERSION EFFICIENCY}

All power semiconductor switches have either a built-in voltage and a series resistance or just a series resistance. In any case, there are conduction and switching losses on the power semiconductors.

The more switches there are on the main current control path, the higher the conduction losses of the system. The series architecture has only two devices in the main current path. The number of devices in the DC distribution case depends on the DC-DC converter architecture selected, but it will still be more than in the series architecture. The multilevel converters usually have two devices per number of levels conducting the load current at once, which is much more than the series and DC distribution architectures. The HFAC architecture has many more switches, because of the requirement for the bidirectional switches in the secondary of the highfrequency transformer. 
As far as the switching losses are concerned, multilevel architectures will be the most efficient if they are switched at the fundamental frequency; however, overall, their losses are higher than but comparable to those of the DC distribution architecture.

\subsection{EASE OF MASS CUSTOMIZATION TO ENABLE MASS PRODUCTION TO DRIVE DOWN COSTS}

Four-pack and six-pack power modules are commercially available; however, bidirectional switches are not commercially abundant. Therefore, presently, it is easier to massproduce DC-DC converters and inverters than AC-AC converters, which makes the HFAC distribution architecture the most difficult to mass-produce today. This is bound to change in the future if the interest in AC-AC converters increases.

For a comparison of the ease of mass customization, assume that it is possible to build any of the power converter modules. Then the question would be which architecture is easier to customize for different power levels. For a higher power level, the following are true.

- Series architecture: The system requires a higher power DC-DC converter and/or inverter module because there will be either higher voltage across the power devices or higher current going through them.

- Multilevel and cascaded multilevel architectures: The power devices see only the fuel cell voltage. If the load current were increased, then these systems would require power modules with higher current ratings because each power module carries the load current.

- DC bus distribution architecture: Each DC-DC converter sees the fuel cell voltage and carries a share of the load current. Unless a higher DC bus voltage is required, there is no need to upgrade the DC-DC converter. The only requirement for higher current would be adding more fuel cells and DC-DC converter modules. If only one inverter on the DC bus is required, then the low power inverter must be replaced by a high-power one. However, if two different AC outputs are required, then simply another inverter can be added.

- HFAC distribution architecture: The arrangement is similar to that for the DC bus distribution architecture but the DC-DC converter is replaced with an H-bridge inverter and the inverter with an HFAC-AC converter. Another fundamental 
difference is that higher power levels in the HFAC distribution architecture also require a higher-power transformer.

Comparing the five architectures, the DC bus distribution architecture is the easiest for mass customization. The next easiest are the HFAC distribution architecture and the series architecture. The multilevel architectures would be worse than the series architecture because they would need more power devices upgraded. 


\section{LEVEL REDUCTION TECHNIQUE FOR MULTILEVEL CONVERTERS}

\subsection{LEVEL REDUCTION TECHNIQUE USING A CASCADED MULTILEVEL DC-DC CONVERTER}

Residential applications and others - including hospitals, schools, and apartment buildings - have a daily load profile with several hours of full-load operation and several hours of low-load operation during each day. As explained earlier, when fuel cells are configured in a series architecture with a three-phase inverter (Case A), ten fuel cells are required to maintain 396.3 $\mathrm{V}$ for the DC-link. When the load current decreases, the DC link voltage increases to $742 \mathrm{~V}$, which requires derating of the inverter devices to address the increased voltage stress.

One solution to limit the DC-link voltage is using series architecture with DC-DC regulators (Case B) to maintain constant voltage to the inverter. However, the introduction of a DC-DC converter increases the cost without much of a benefit, considering that isolation or voltage boost might not be essential in this application.

Case B keeps the DC-link voltage constant so that the inverter switches need not necessarily be derated; however, the DC-DC converter switches will need to be derated to account for the no-load fuel cell module output voltage of $742 \mathrm{~V}$.

A better solution is the level reduction technique, which inhibits fuel cell modules one by one when the load current decreases. Then the voltage across the power switches is reduced, still maintaining the voltage and power required by the inverter and the load, respectively.

As an example, consider the no-load operation in Case A where ten fuel cells are operating at any load current. To generate $396.3 \mathrm{~V}$ only

$$
n>\frac{V_{D C}}{V_{f c, N L}}=\frac{396.3 \mathrm{~V}}{74.2 \mathrm{~V}}=5.34,
$$

$\mathrm{n}=6$ fuel cell modules in series would be sufficient; if four fuel cell modules were inhibited at no load, then the DC-link voltage would be much less, $445.2 \mathrm{~V}$ as opposed to $742 \mathrm{~V}$. As the load current increases more fuel cell modules would be put on line. At full-load ten fuel cells would still be supplying power to the load.

Figure 5.1 shows the static characteristics of up to ten fuel cells in series and how the level reduction works to keep the output voltage close to the required voltage. 


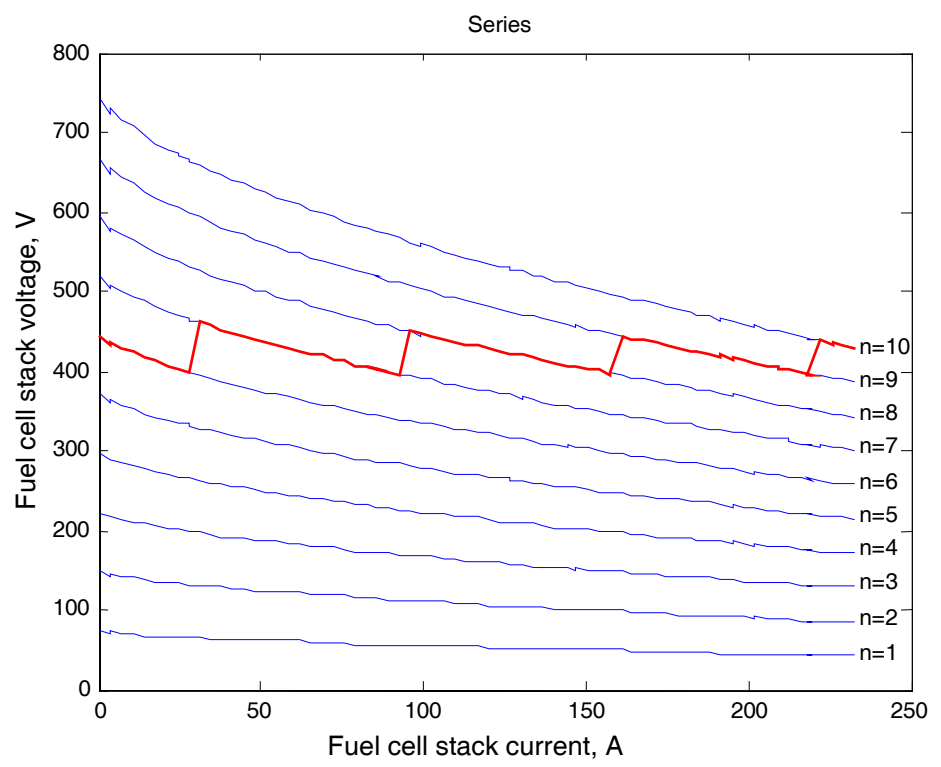

Fig. 5.1. Static characteristics for up to 10 fuel cells in series and level reduction technique.

Using Eq. (5.1), the DC-link voltages with the level reduction technique over the full range of load currents are plotted in Fig. 5.2. As seen here, with level reduction, the maximum DC-link voltage is around $450 \mathrm{~V}$ rather than allowing the undesirable $742 \mathrm{~V}$.

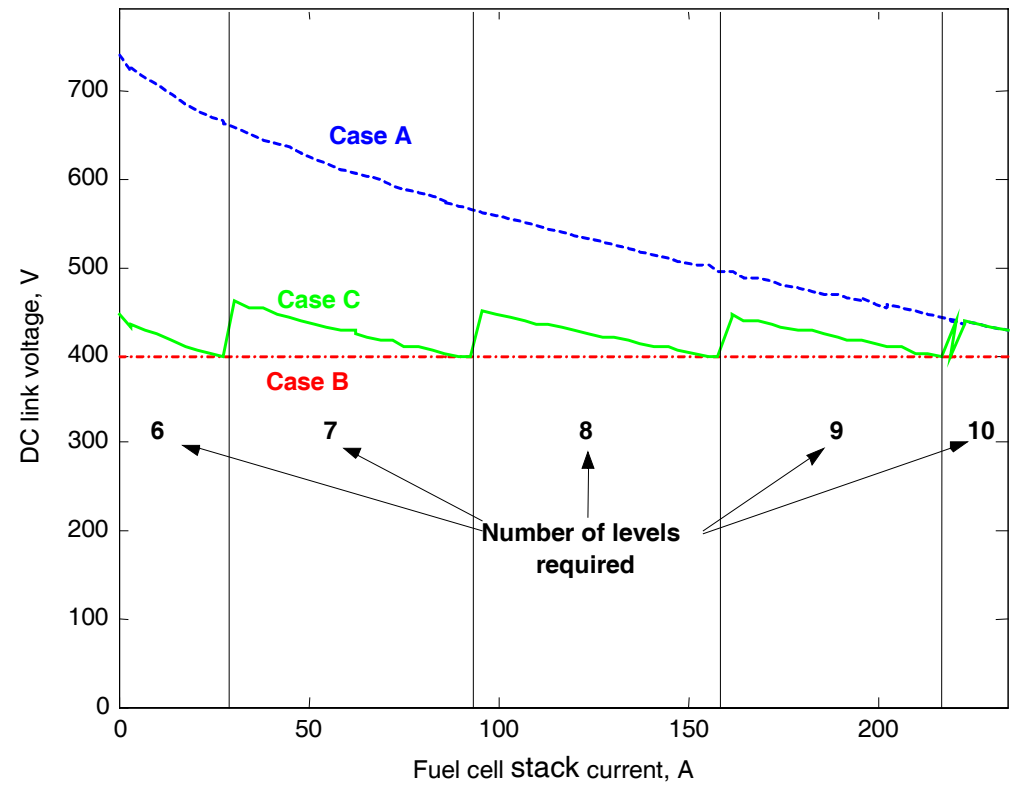

Fig. 5.2. Multilevel DC-DC converter output voltage for each case. 


\subsubsection{Case G - Multilevel DC-DC Converter}

An ideal converter for the application of the level reduction technique is the cascaded multilevel DC-DC converter shown in Fig. 5.3, which was originally introduced in [16, 17] for a motor drive application.

Each fuel cell has an associated vertical $\left(\mathrm{S}_{\mathrm{V}}\right)$ and a horizontal $\left(\mathrm{S}_{\mathrm{H}}\right)$ switch. When $\mathrm{S}_{\mathrm{H}}$ is on and $S_{V}$ is off, the fuel cell supplies power to the load. On the other hand, if $S_{V}$ is on and $S_{H}$ is off, then the fuel cell does not supply any power; thus it is inhibited.

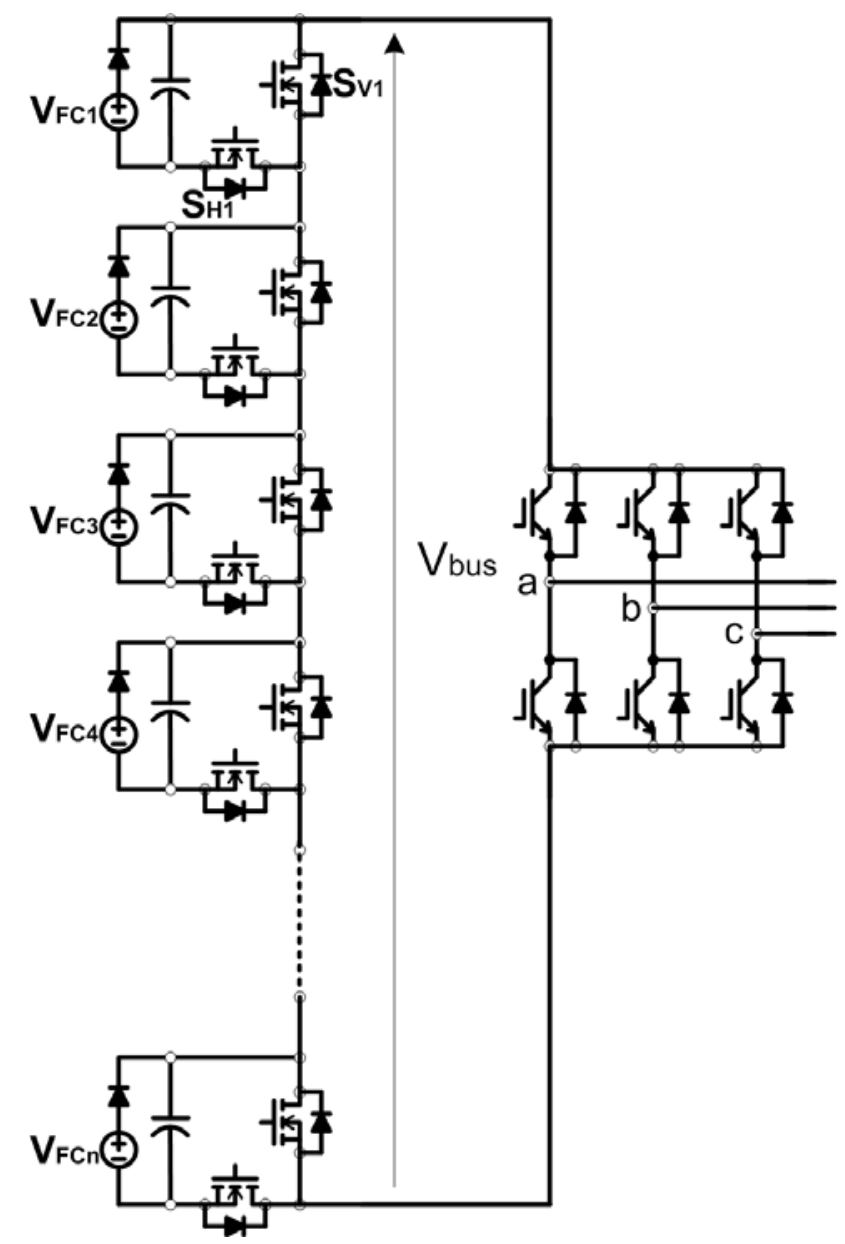

Fig. 5.3. Multilevel DC-DC converter connected to a three-phase inverter.

Note that the level reduction technique is proposed for applications such as apartment buildings, schools, and hospitals where the load varies throughout the day. However, the load variation is generally not fast; therefore, high-frequency switching of the multilevel DC-DC converter is not a problem. Since this converter merely changes the DC voltage level when required, the control of the converter is rather simple. 
A voltage sensor is required to monitor the fuel cell voltage; then, the controller can use Eq. (5.1) to calculate $n$ and inhibit $\left(n_{\text {total }}-n\right)$ fuel cell modules.

In Eq. (5.1), all the fuel cells have been assumed identical. The level reduction technique would still work with fuel cells producing different output voltages that are connected to the same multilevel converter. The difference would be that the fuel cell with the least voltage would be inhibited first.

As seen in Fig. 5.3, a three-phase inverter is still required for the inversion. This inverter will require a variable modulation index to compensate for the varying DC-link voltage, but this variation will not be as extreme as the one in Case A, Series Architecture with three-phase inverter.

\subsubsection{Evaluation}

\subsubsection{Power supplied}

For the same current value required by the inverter, the power supplied by the fuel cells for each case is calculated assuming 100\% efficiency for the DC-DC converters; the results are plotted in Fig. 5.4. Since the DC-link voltage is kept constant in Case B, the power supplied is proportional to the load current. The difference between the curves in other cases and in Case B is the excess power. As expected, Case A produces much more excess power for the same current than the other cases.

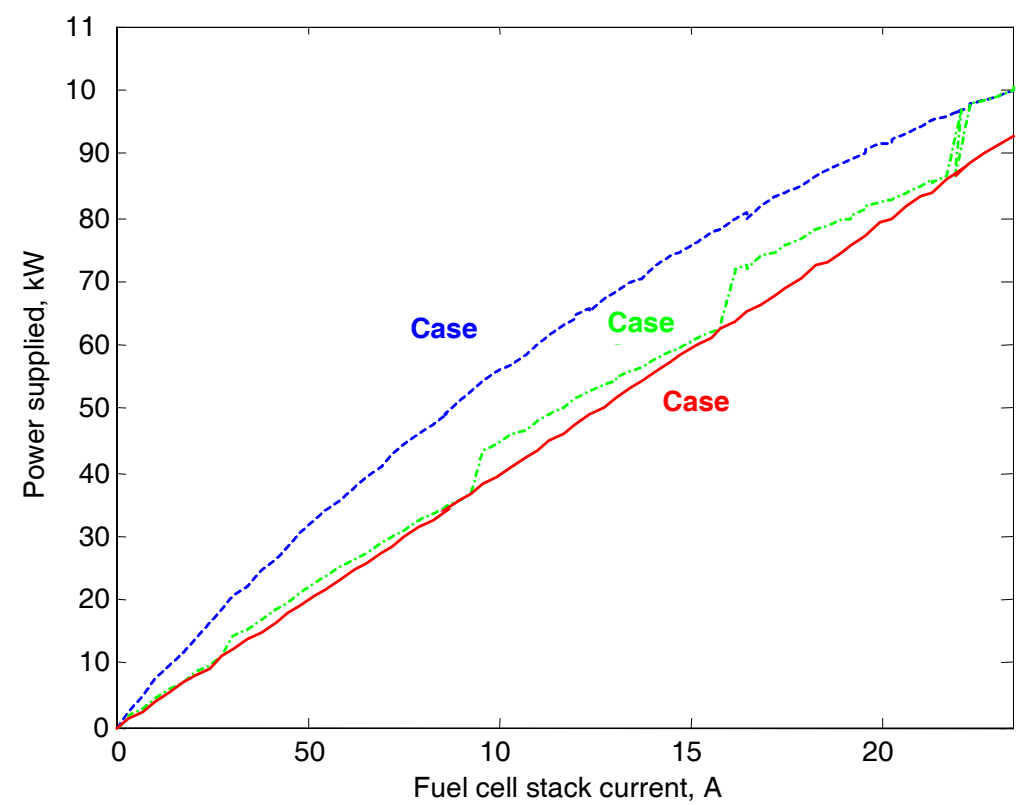

Fig. 5.4. Power supplied for each case. 


\subsubsection{Fuel cell utilization}

Fuel cell utilization in this paper is defined as the ratio of the power required by the inverter to the power supplied by the fuel cells for the same load current.

$$
\text { F.C.U. }\left.\equiv \frac{P_{\text {required }}}{P_{\text {supplied }}}\right|_{\text {at the same load current }} \text {. }
$$

For Cases A and G, the current through the fuel cells is equal to the current drawn by the inverter; therefore,

$$
\text { F.C.U. } \equiv \frac{V_{D C} \cdot I}{V_{F C} \cdot I}=\frac{V_{D C}}{V_{F C}} .
$$

For Case B, the fuel cell utilization is the same as the efficiency of the DC-DC converter, which is assumed to be $100 \%$.

Figure 5.5 shows a plot of the fuel cell utilization for each case. As seen in this figure, Case B has better fuel cell utilization than Case G. This conclusion, however, is deceptive because it is overlooking the point that in Case G, at any time there are up to four fuel cells idling. Factoring this fact in the fuel cell utilization, modified fuel cell utilization can be defined as

$$
\text { M.F.C.U. }=\text { F.C.U. } \frac{n_{\text {total }}}{n} .
$$

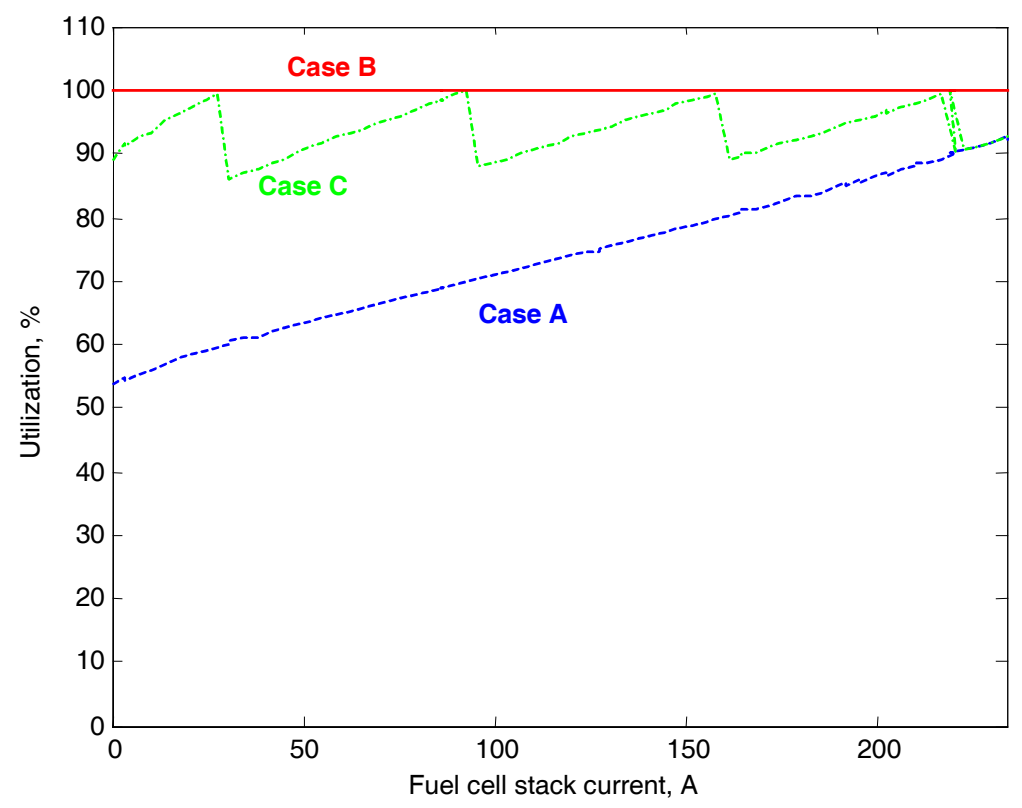

Fig. 5.5. Fuel cell utilization for each case. 
The extra term in Eq. (5.4) is one for Cases A and B at all current levels, but it varies between 1.67 (10/6) and 1 (10/10) for Case G. The resulting utilization plot is shown in Fig. 5.6, where it is seen that the utilization in Case $G$ is much higher than the utilization in the other cases at lower currents. Around full load, the utilization for Case $G$ is similar to the utilization for the other two cases.

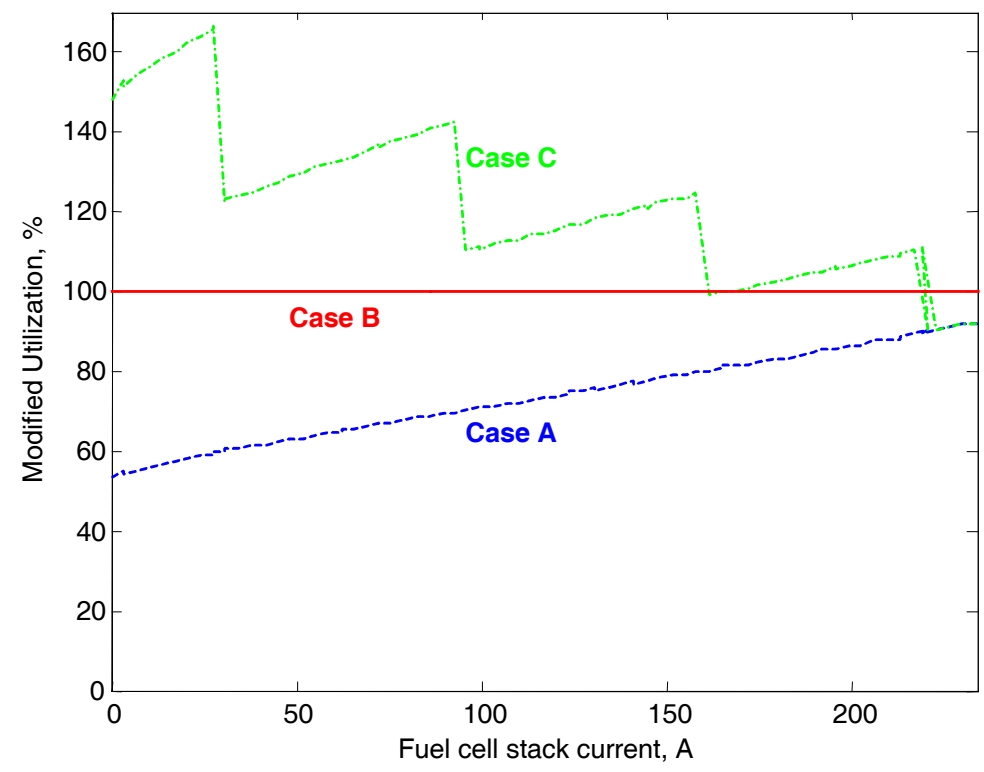

Fig 5.6. Modified fuel cell utilization for each case.

\subsubsection{Comparison}

Case $\mathrm{A}$ is the simplest architecture and has the minimum device count; however, the inverter switches have to be rated at twice the DC-link voltage for full-load operation so that the system can operate at all loads.

Case B uses a DC-DC converter, so the inverter switches do not have to be overrated; however, the DC-DC converter switches have to be rated higher. This converter also introduces bulky passive components and more expense.

Case $\mathrm{G}$ has two extra switches per fuel cell; therefore, the system has a higher component count, but the additional expense is lower considering that the switches are of the less expensive low-voltage type. Another disadvantage is that there is always a switch per fuel cell in the load current path, no matter whether the fuel cell is inhibited, causing extra conduction losses.

Case $\mathrm{G}$ also has the advantages of modularity and increased reliability with redundancy and ease of expansion. This means that if a fuel cell module fails, the system will continue to 
operate. The failing unit can be replaced as a module together with its switches in a short time, decreasing the down time for repairs.

In Case G, for most of the load current range, one or more fuel cells are idling. These can be used to charge batteries or for other uses to increase the fuel cell utilization and the system efficiency. If the idling fuel cells are not needed for other applications, they can be left idle, prolonging the life of the fuel cell. Another option currently being researched by the DOE is the capability to reverse solid oxide fuel cells to generate hydrogen in the Hydrogen Economy of the future. If the selection of fuel cells to be inhibited is rotated among all the existing fuel cells, the life expectancy of the whole system can be increased compared with other cases.

\subsubsection{Parallel Operation}

Ten $10 \mathrm{~kW}$ fuel cell modules can produce $100 \mathrm{~kW}$; for a $200 \mathrm{~kW}$ application, if ten fuel cell modules in series would satisfy the voltage constraint, then two modules have to be put in parallel before being connected in series to achieve the power rating.

An analogous parallel system to the multilevel DC-DC converter to connect fuel cells in parallel is shown in Fig. 5.7. Each fuel cell comes with a series diode and a switch. The diode prevents current from flowing into the fuel cell module, and the switch isolates/inhibits the fuel cell if needed. As in the level reduction technique, different numbers of fuel cell modules can be inhibited to control the output voltage when the load decreases.

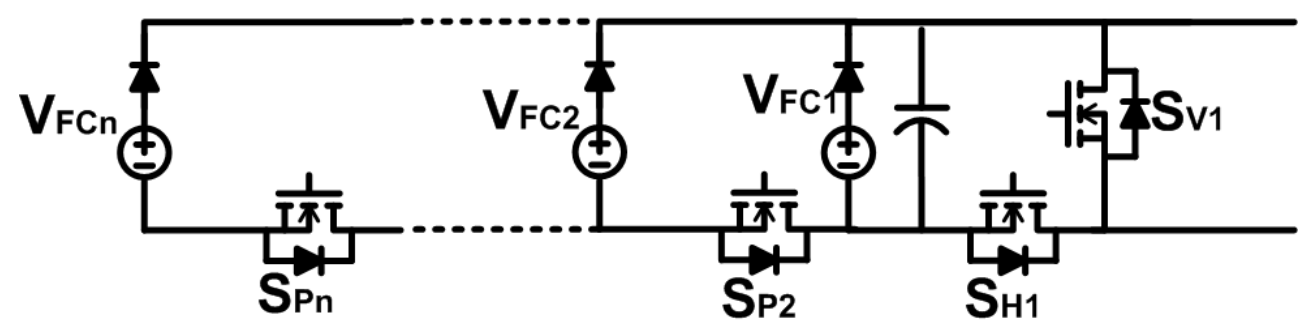

Fig. 5.7. Proposed parallel operation of fuel cells.

To demonstrate the operation of the proposed parallel fuel cell connection, Fig. 5.8 shows the static characteristics of up to five fuel cell modules connected in parallel. Assume that the system has to keep a $55 \mathrm{~V}$ command output voltage at any current value. It can be observed Fig. 5.8 that for a current range of 100-500 A, this voltage can be maintained with some error by inhibiting fuel cells when required. In the rest of the current spectrum, the error is much higher. However, if the fuel cell modules are not switched in or out, the fuel cell output voltage would be worse varying along the $n p=5$ fuel cell characteristics without any possibility of regulating the 
command voltage around a certain value. It can also be observed in Fig. 5.8 that for lower output voltage commands, the voltage can be controlled for a wider current range; the widest is for a voltage command of $42.91 \mathrm{~V}$, the minimum voltage a fuel cell can supply.

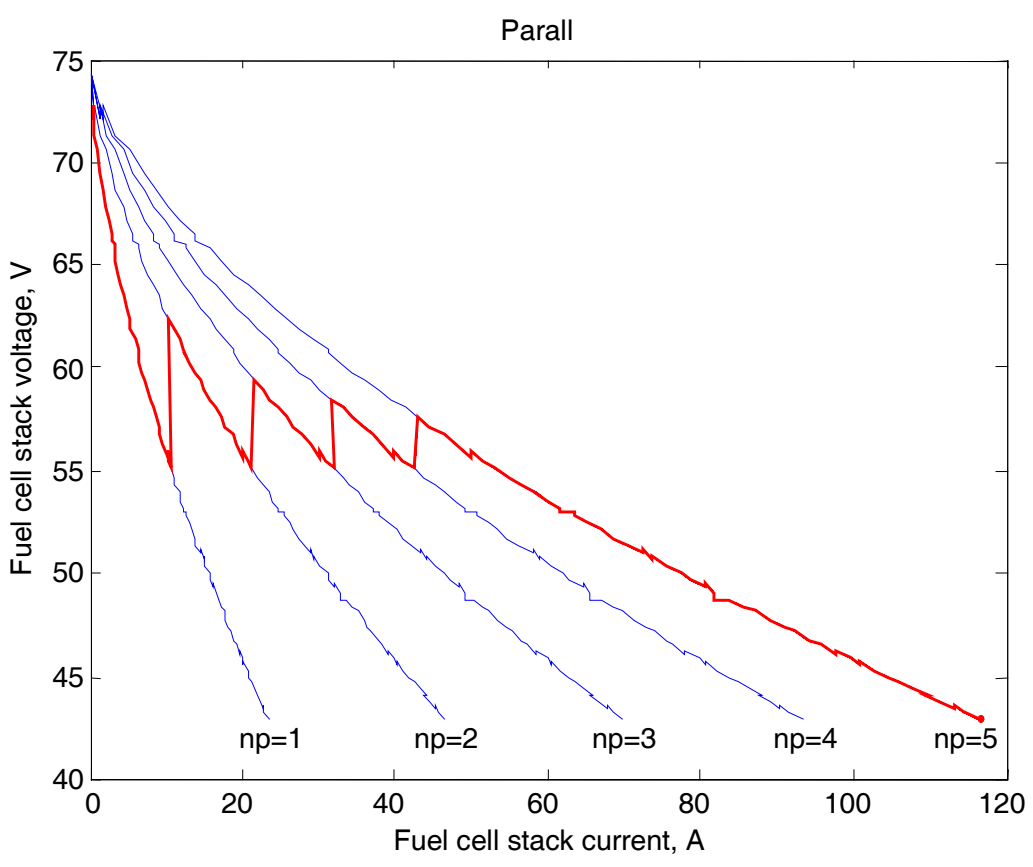

Fig. 5.8. Static characteristics for up to five fuel cells in parallel.

\subsubsection{Parallel-Series (Matrix) Operation}

In a multilevel DC-DC converter shown in Fig. 5.3, all the fuel cell modules can be replaced by parallel fuel cell modules as shown in Fig. 5.7, producing a parallel-series or a matrix connection for high-power applications. This increases the complexity of the control and introduces additional switch losses, but it should still be considered, since present high-power fuel cells are made up of conventional series and parallel connections of fuel cell stacks.

As an example, if a $500 \mathrm{~kW}$ application is considered, then Figs. 5.1 and 5.8 can be combined to demonstrate what happens if ten parallel strings of five fuel cell modules are connected in series in a multilevel DC-DC converter architecture. Figure 5.9 shows what the static characteristics of this combination would look like. Notice that the dotted (green) line shows the output voltage of ten fuel cell modules with level reduction without the proposed parallel operation. The thick solid (red) line, however, shows the output voltage closer to the set point of $396.1 \mathrm{~V}$ with the proposed parallel operation. 


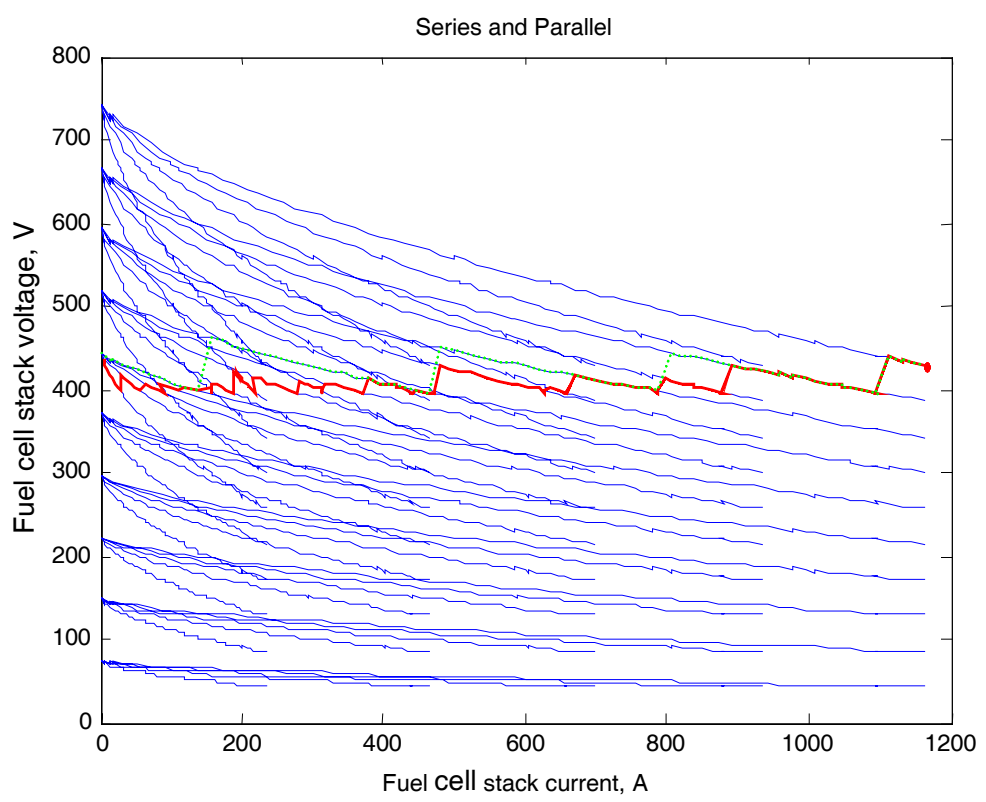

Fig. 5.9. Static characteristics for up to five fuel cells in parallel and up to ten in series.

Even though the output voltage is closer to the command value with the newly introduced technique, the gain for most applications is predicted to be minimal considering the higher losses and higher cost introduced by the additional switches.

\subsection{LEVEL REDUCTION TECHNIQUE USING CASCADED MULTILEVEL INVERTERS}

An alternative to the DC-DC converter architecture is a cascaded multilevel inverter. The advantage of this architecture over the earlier one is that all the switches of the multilevel inverter architecture will have low voltage ratings, unlike the higher voltage ratings of the inverter switches in the previous one. However, a disadvantage is that there will be two switches conducting the load current for each fuel cell, compared with one in the other architecture. These two switches reduce the efficiency of the system because of the additional conduction losses. Therefore, it is not wise to use a multilevel inverter system for low-voltage fuel cells, but it should rather be considered for higher-voltage fuel cells.

For a multilevel inverter to operate at fundamental switching frequency, the switching angles should be carefully selected so that the THD is reduced. Solutions for angles for inverters with different numbers of levels have been presented in the literature [13,14]. These angles are stored in look-up tables with respect to the modulation indices. For a reduced level multilevel inverter, several sets of these angles have to be stored; and an algorithm has to be developed to determine when to reduce the levels, which increases the control complexity. 
A multilevel fundamental frequency sine-triangle wave comparison technique inspired from multilevel PWM [18-20] is introduced to simplify the control system. Figure 5.10 shows the modulating waveform and the carrier waveforms for a 7-level (3-fuel cell module) system. Because there are three converters available, three carrier waves are required, one for each converter. These carrier waves are $\left(\mathrm{V}_{\mathrm{c}} / 3\right)$ peak-to-peak and $\left(\mathrm{V}_{\mathrm{c}} / 3\right)$ offset from each other where $\mathrm{V}_{\mathrm{C}}$ is equivalent to the peak of the carrier wave in sinusoidal PWM for a single converter. For an $n$-converter system, the carrier waves would be $\left(V_{c} / n\right)$ peak-to-peak and $\left(V_{c} / n\right)$ offset from each other.

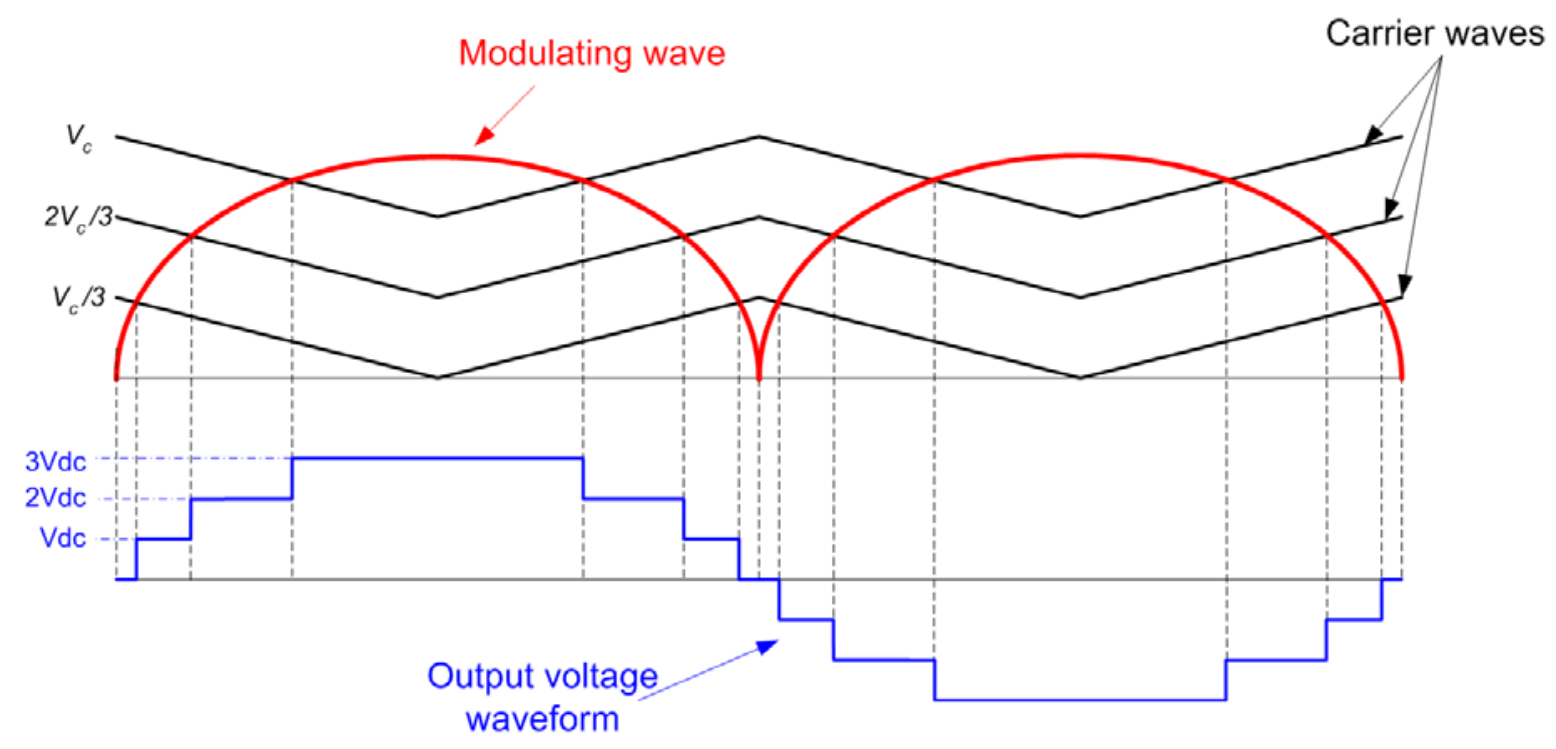

Fig. 5.10. Fundamental switching sine triangle wave comparison.

As can be observed from Fig. 5.10, if the amplitude of the modulating wave is greater than $\left(2 \mathrm{~V}_{\mathrm{c}} / 3\right)$, no $\mathrm{H}$-bridges are inhibited. If it is between $\left(2 \mathrm{~V}_{\mathrm{c}} / 3\right)$ and $\left(\mathrm{V}_{\mathrm{c}} / 3\right)$, then one inverter is inhibited; and if it is less than $\left(\mathrm{V}_{\mathrm{c}} / 3\right)$, two inverters are inhibited.

The modulation index for a multilevel inverter is defined as $m_{a} \equiv V_{1} /\left(n \cdot 4 \cdot V_{D C} / \pi\right)$, where $n$ is the number of levels and $\mathrm{V}_{\mathrm{DC}}$ is the voltage input to each H-bridge. Figure 5.11 shows the input-output relationship of a 13-level inverter for the fundamental frequency sine-triangle comparison system. For each $\mathrm{m}_{\mathrm{a}}$ in the $\mathrm{x}$-axis, the $\mathrm{y}$-axis shows the scaling factor that gives the peak output voltage when multiplied by $V_{D C}$. This relationship is not linear for any $m_{a}$ as would have been expected when compared with other similar modulation techniques.

The modulation index of an n-level inverter depends on two variables, the DC input (fuel cell module output) voltage and the output fundamental voltage. For a constant fundamental 
output voltage, if the DC input voltage increases, then $\mathrm{m}_{\mathrm{a}}$ needs to decrease. The voltage in a fuel cell system will increase in low load conditions; therefore, the modulation index will decrease. Figure 5.11 shows that as the modulation index decreases, the levels will be reduced automatically. The level reduction is simulated for a 6-fuel cell module multilevel inverter, and the transition from high to low load or from 13 levels to 11 levels is illustrated in Fig. 5.12.

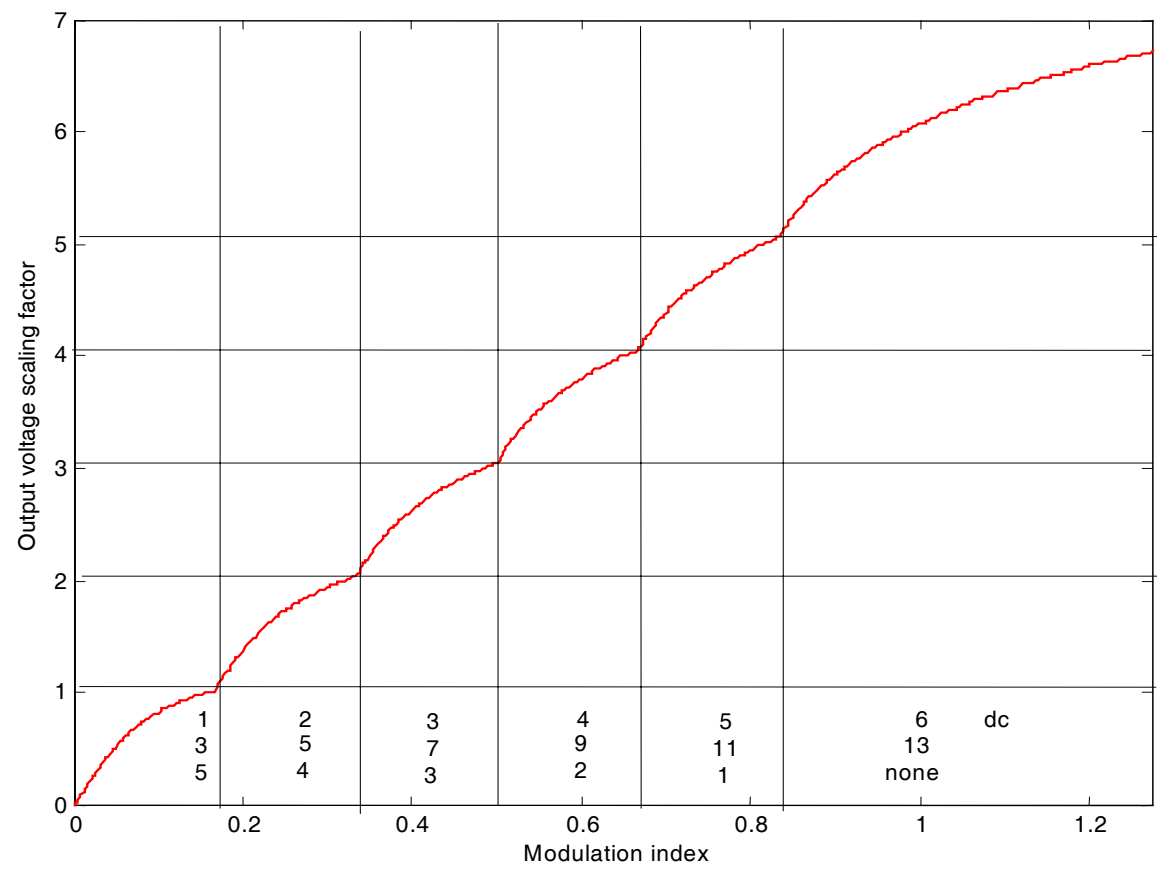

Fig. 5.11. Modulation index correction plot.

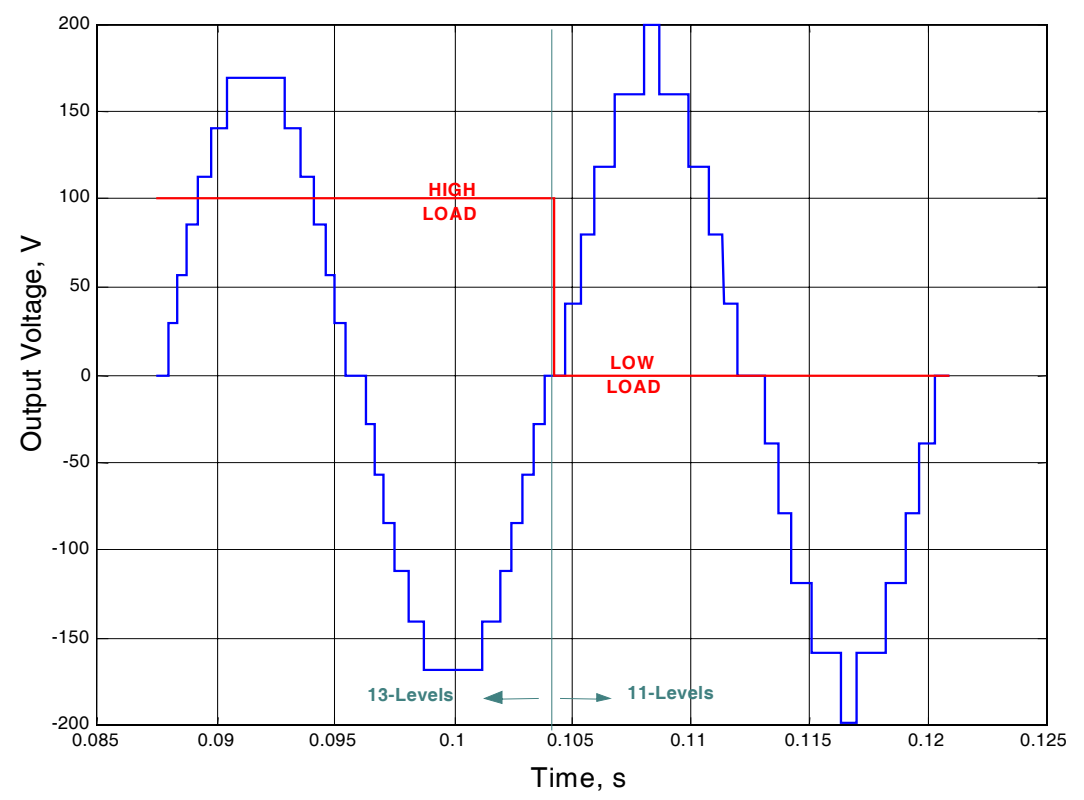

Fig. 5.12. Output voltage waveform simulated for high-load to low-load transition. 
The inhibited H-bridges and fuel cell modules can be used to charge batteries to increase the efficiency and the utilization of the fuel cells further.

Since a simple sine-triangle comparison at fundamental frequency is being used, instead of switching angle optimization techniques, THD might be a concern. Figure 5.13 shows the THD of the output voltage waveform when level reduction control with sine-triangle comparison is used. Note that for the calculation, harmonics up to and including the 41st order harmonic are used; and the triplen harmonics are ignored since they will cancel each other in a three-phase system. The plot shows that, as expected, THD decreases at higher modulation indices, i.e., when more levels are present. It must be noted that this is the THD for the unfiltered voltage waveform. If a further reduction in THD is required, then the frequency of the carrier wave can be increased for low-frequency PWM operation.

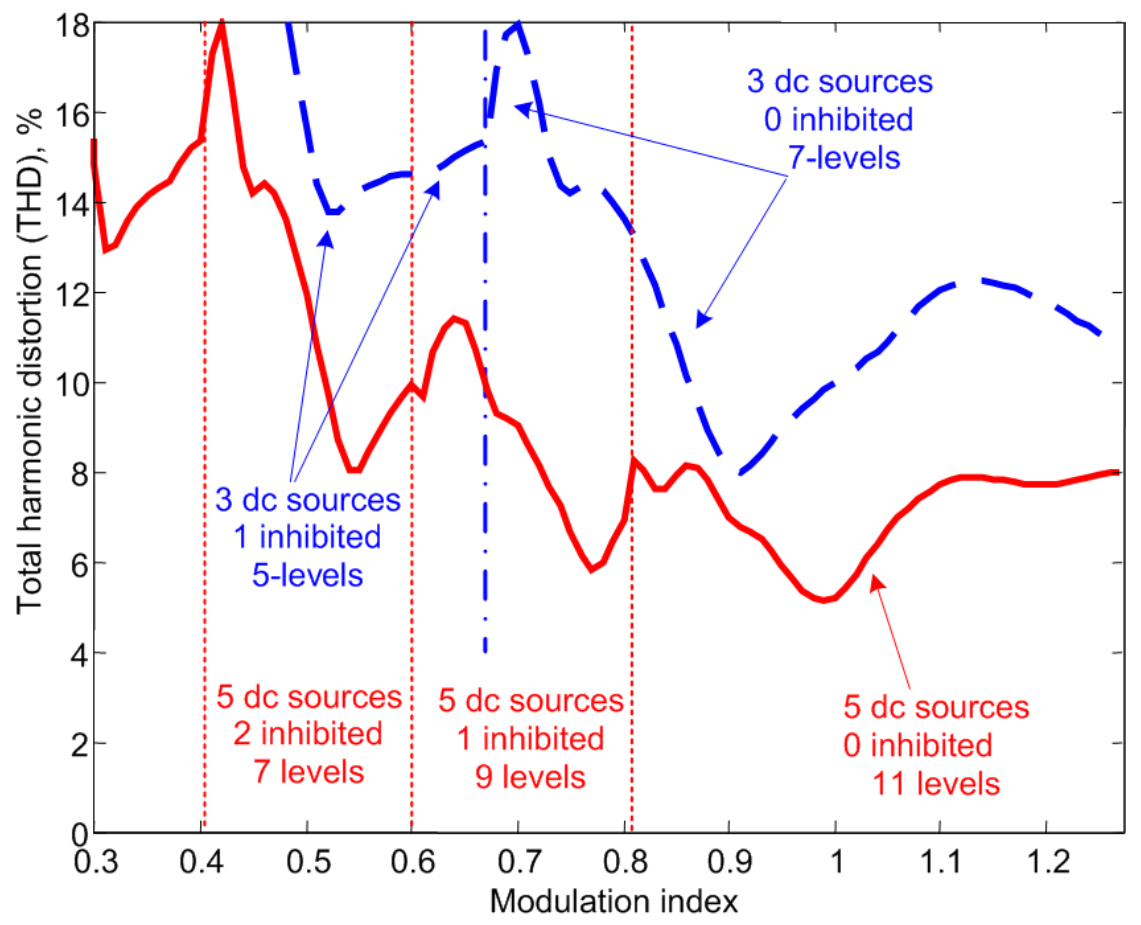

Fig. 5.13. THD with respect to the modulation index.

\subsection{EXPERIMENTAL RESULTS}

The control algorithm has been tested on a $10 \mathrm{~kW}$ cascaded multilevel inverter using the fundamental switching sine triangle wave comparison shown in Fig. 5.10. Since no fuel cell modules were available in the lab, possible fuel cell characteristics were simulated; and the multilevel inverter was operated in two conditions: low load and full load. At low loads, the fuel cell voltage increases and consequently the modulation index decreases. In this case, for a 
modulation index of 0.42 , seven levels are enough to produce the required fundamental output voltage as shown in Figs. 5.14 and 5.15.

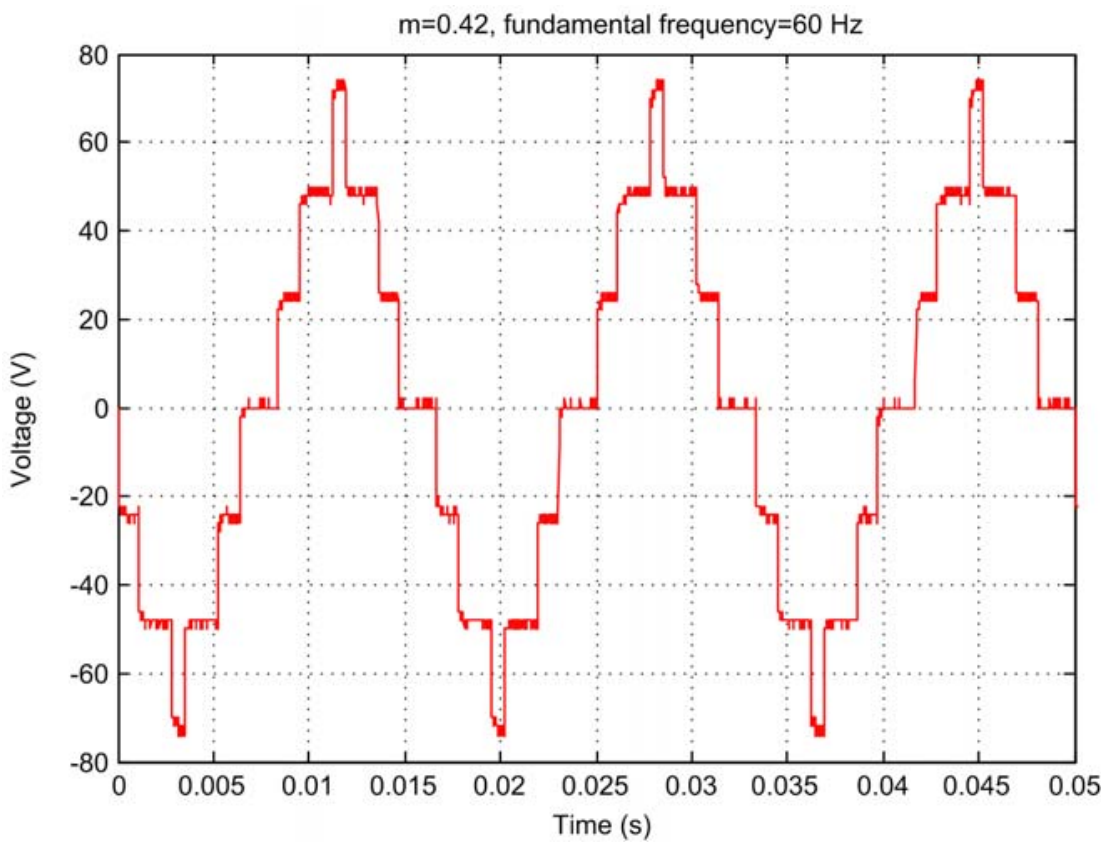

Fig. 5.14. Seven-level output voltage waveform for low fuel cell load.

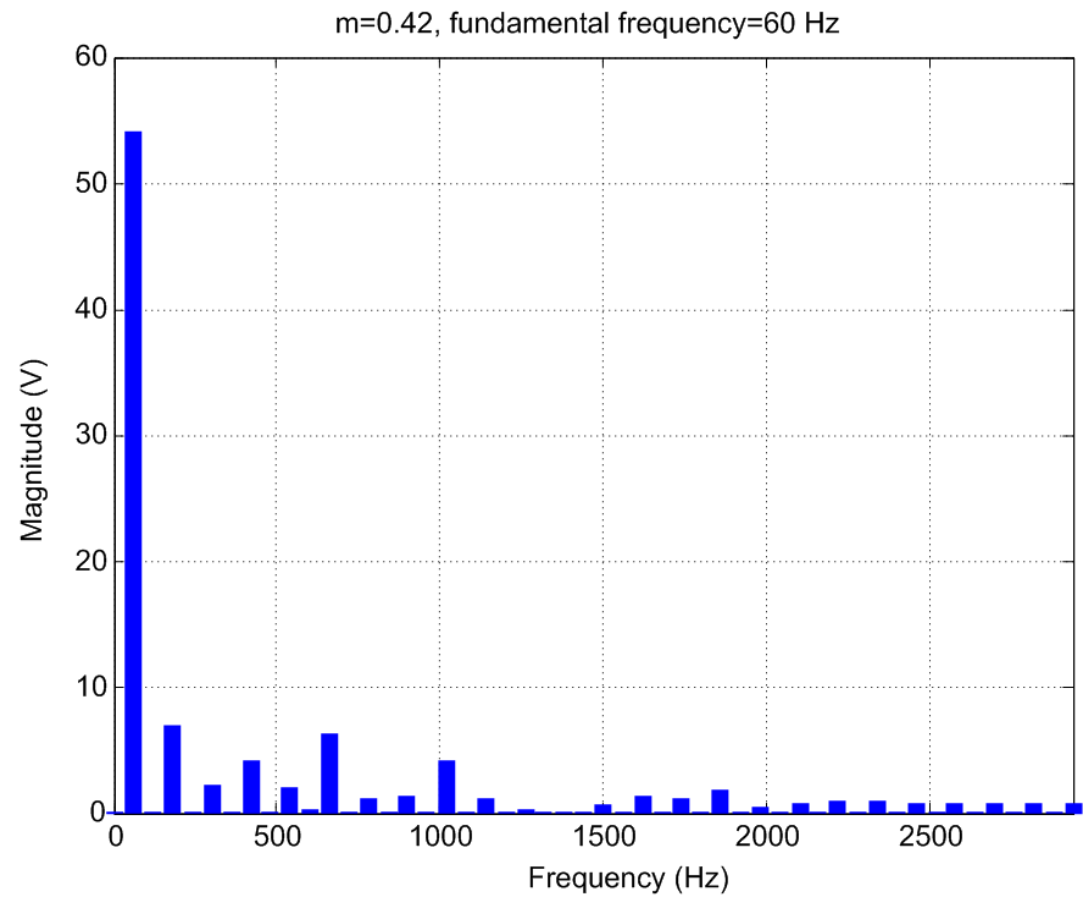

Fig. 5.15. FFT of the voltage waveform in Fig. 5.14. 
For higher loads, the fuel cell voltage decreases and the modulation index increases. For a modulation index of 0.85, the number of required levels increases to 11, as shown in Figs. 5.16 and 5.17 .

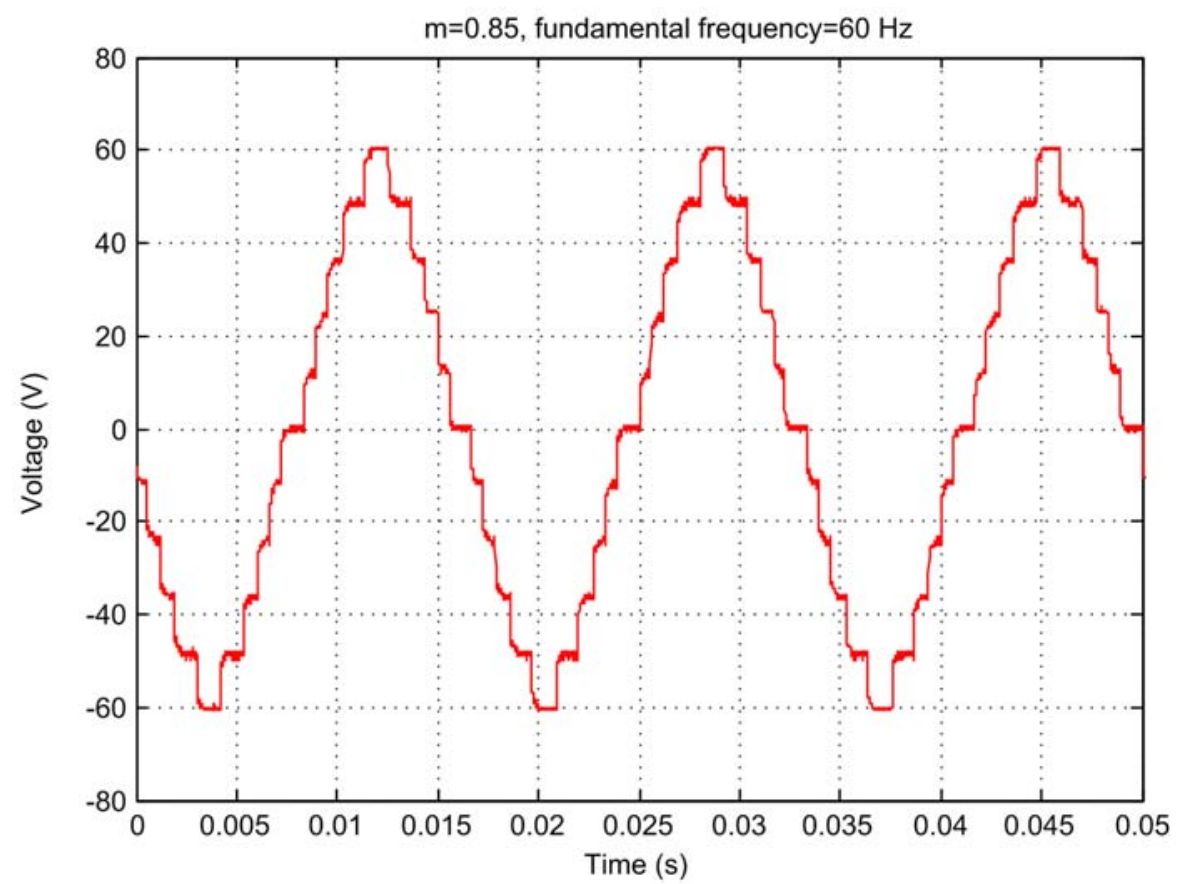

Fig. 5.16. Eleven-level output voltage waveform for high fuel cell load.

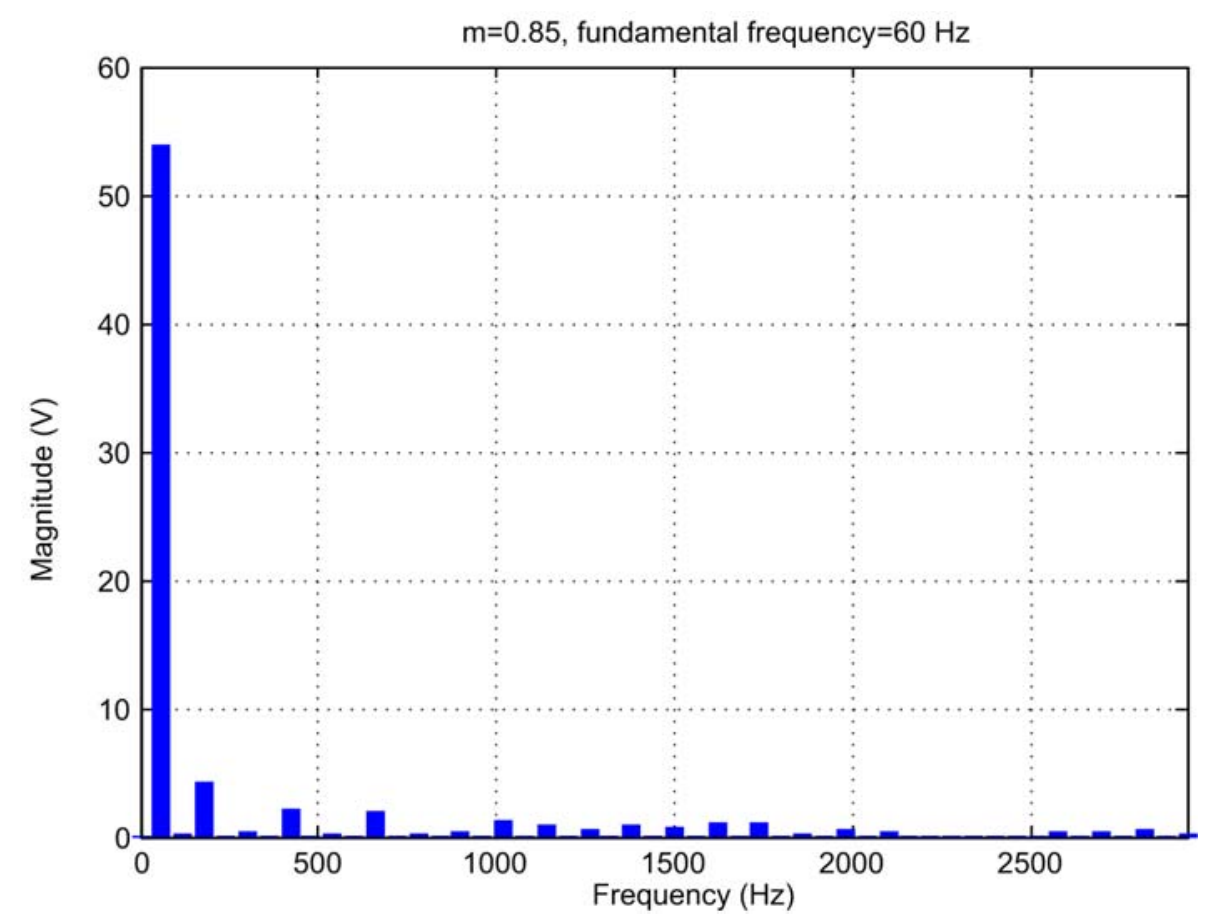

Fig. 5.17. FFT of the voltage waveform in Fig. 5.16. 
THD values are given as $17.3 \%$ for $m_{a}=0.42$ and $7.12 \%$ for $m_{a}=0.85$. As expected for lower modulation index, the THD is worse. To improve the THD of the output voltage waveforms, a filter could be employed. Another alternative is to increase the frequency of the carrier wave so that the output waveform will be more like a low-frequency multilevel PWM voltage. 


\section{CONCLUSIONS}

Five different architectures to aggregate multiple SOFC modules were subject to a preliminary trade study. The advantages and the disadvantages of each architecture were stated in comparison with the other architectures. It must be noted that even though the focus of this study was on SOFC modules, the architectures presented can also be applied to other fuel cell modules.

Novel multiple input converter topologies for fuel cells have been reviewed. With reduced level control technique exploiting the V-I characteristics of fuel cells, the need for derating power semiconductors in fuel cell systems is eliminated. By inhibiting some of the fuel cells and using the inhibited fuel cells in other applications, such as charging batteries, the system efficiency and the fuel cell utilization increase. If these fuel cells are left idling, then the life expectancy of the system increases.

In addition to these advantages, using a multilevel converter also brings the advantages of modularity and increased reliability.

For the multilevel inverter, a fundamental switching sine-triangle comparison method is introduced. This method decreases the complexity of level reduction control for multilevel inverters by eliminating the need to store separate switching angle look-up tables for multilevel inverters for each number of DC sources.

The level reduction technique is also applicable to other fuel cell-fed multilevel inverters.

\subsection{NOTES AND RECOMMENDATIONS}

- Presently, most commercially available non-SECA fuel cell modules have a DC-DC regulator or an inverter to condition the fuel cell voltage. Some of the architectures presented in this report require different converters at the output of the fuel cell stack. This must be considered in the design of the SECA modules if any of these architectures are to be used. One solution might be for the SECA module to output raw stack voltage. Then the required power conditioning module - such as a DC regulator, an inverter, or a high frequency inverter — can be added externally. 
- For safety reasons, most of the present fuel cell modules are grounded to the case; however, some of the multiple input architectures in this report would require floating outputs such as cascaded multilevel converters. If the SECA SOFC modules have an option to easily float their output, then it would be easier to apply the architectures in this report.

- Presently, there is no standard on fuel cell output voltage level. From the power electronics perspective, it important to have this standard so that converters can be designed with compatible devices. For higher-efficiency power conversion, it is also important for the SECA fuel cell modules to deliver higher voltages. 


\section{REFERENCES}

[1] C. A. Forbes and J. F. Pierre, "The Solid Fuel-Cell Future,” pp. 40-44 in IEEE Spectrum, 30(10), October 1993.

[2] D. J. Hall and R. G. Colclaser, "Transient Modeling and Simulation of a Tubular Solid Oxide Fuel Cell” pp. 749-753 in IEEE Transactions on Energy Conversion, 14(3), September 1999.

[3] Solid State Energy Conversion Alliance webpage, http://www.seca.doe.gov/.

[4] C. D. M. Oates, R. W. Crookes, S. H. Pyke, and R. T. Leah, "Power Conditioning for Solid Oxide Fuel Cells,” pp. 12-17 in International Conference on Power Electronics, Machines, and Drives, June 4-7 2002.

[5] K. W. E. Cheng, D. Sutanto, Y. L. Ho, and K. K. Law, "Exploring the Power Conditioning System for Fuel Cell," pp. 2197-2202 in IEEE Power Electronics Specialists Conference, June 17-21, 2001.

[6] K. Sedghisigarchi and A. Feliachi, "Control of Grid-Connected Fuel Cell Power Plant for Transient Stability Enhancement,” pp. 383-388 in IEEE Power Engineering Society Winter Meeting, January 27-31, 2002.

[7] DOE Fuel Cell Handbook, 6th Edition, pp. 2-9 - 2-14, EG\&G Technical Services, Inc., DOE/NETL-2002/1179, 2002.

[8] J. Larminie and A. Dicks, Fuel Cell Systems Explained, pp. 39-52, John Wiley \& Sons, England.

[9] G. Hoogers, Fuel Cell Technology Handbook, pp. 4-5 - 4-9, CRC Press, 2003.

[10] L. A. Chick, J. W. Stevenson, R. E. Williford, and S. P. Simner, PNNL SOFC Excel Spreadsheet Model, PNNL-SA-36950, Pacific Northwest National Laboratory, August 2003.

[11] R. Gemmen, "Analysis for the Effect of Inverter Ripple Current on Fuel Cell Operating Condition,” Power Electronics for Fuel Cells Workshop, Irvine, California, August 8-9, 2002.

[12] L. M. Tolbert and F. Z. Peng, "Multilevel Converters as a Utility Interface for Renewable Energy Systems,” pp. 1271-1274 in IEEE Power Engineering Society Summer Meeting, Seattle, Washington, July 15-20, 2000. 
[13] J. N. Chiasson, L. M. Tolbert, K. J. McKenzie, and Z. Du, "Control of a Multilevel Converter Using Resultant Theory,” pp. 345-354 in IEEE Transactions on Control System Theory, 11(3), May 2003.

[14] L. M. Tolbert, J. N. Chiasson, K. J. McKenzie, and Z. Du, "Control of Cascaded Multilevel Converters with Unequal Voltage Sources for HEV,” pp. 663-669 in IEEE International Electric Machines and Drives Conference, Madison, Wisconsin, June 1-4, 2003.

[15] L. M. Tolbert, F. Z. Peng, and T. G. Habetler, "Multilevel PWM Methods at Low Modulation Indices,” pp. 719-725 in IEEE Transactions on Power Electronics, 15(3), July 2000.

[16] G. J. Su and D. J. Adams, "Multilevel DC Link Inverter for Brushless Permanent Magnet Motors with Very Low Inductance,” pp. 829-834 in IEEE Industry Applications Conference, September 30-October 4, 2001.

[17] G. J. Su, “Multilevel DC Link Inverter,” U.S. Patent No. 6,577,087.

[18] F. Z. Peng, “A Generalized Multilevel Inverter Topology with Self Voltage Balancing,” pp. 611-618 in IEEE Transactions on Industry Applications, 37(2), March-April 2001.

[19] G. Sinha and T.A. Lipo, “A New Modulation Strategy for Improved DC Bus Utilization in Hard and Soft Switched Multilevel Inverters,” pp. 670-675 in 23rd International Conference on Industrial Electronics, Control and Instrumentation, November 1997.

[20] G. Carrara, S. Gardella, M. Marchesoni, R. Salutari, and G. Sciutto, “A New Multilevel PWM Method: A Theoretical Analysis,” pp. 497-505 in IEEE Transactions on Power Electronics, 7(3), July 1992. 


\title{
INTERNAL DISTRIBUTION
}

\author{
1. D. J. Adams \\ 4. B. Ozpineci \\ 2. M. Chinthavali \\ 5. L. M. Tolbert \\ 3. E. C. Fox \\ 6-7. ORNL Laboratory Records

\section{EXTERNAL DISTRIBUTION}

7. Donald Collins, Project Manager - Fuel Cells, National Energy Technology Laboratory, 3610 Collins Ferry Road, P.O. Box 880, Morgantown, West Virginia 26507-0880. 